Understanding Natural SystemsA Perspective for Land-Use Planning in Appalachian Kentucky

GEOLOGICAL SURVEY BULLETIN 1438 



\section{UNITED STATES DEPARTMENT OF THE INTERIOR}

CECIL D. ANDRUS, Secretary

GEOLOGICAL SURVEY

W. A. Radlinski, Acting Director

\section{Library of Congress Cataloging in Publication Data \\ Newell, Wayne L \\ Understanding natural systems.}

(Geological Survey bulletin ; 1438)

Bibliography: p.

1. Geology-Kentucky. 2. Land use-Planning-Kentucky. I. Title II. Series: United States. Geological Survey. Bulletin ; 1438.

QE75.B9 no. 1438 [QE115] 557.3'08s 77-20103

[333.7'09769'1]

For sale by Superintendent of Documents, U.S. Government Printing Office Washington, D.C. 20402

Stock Number 024-001-03066-7 


\section{CONTENTS}

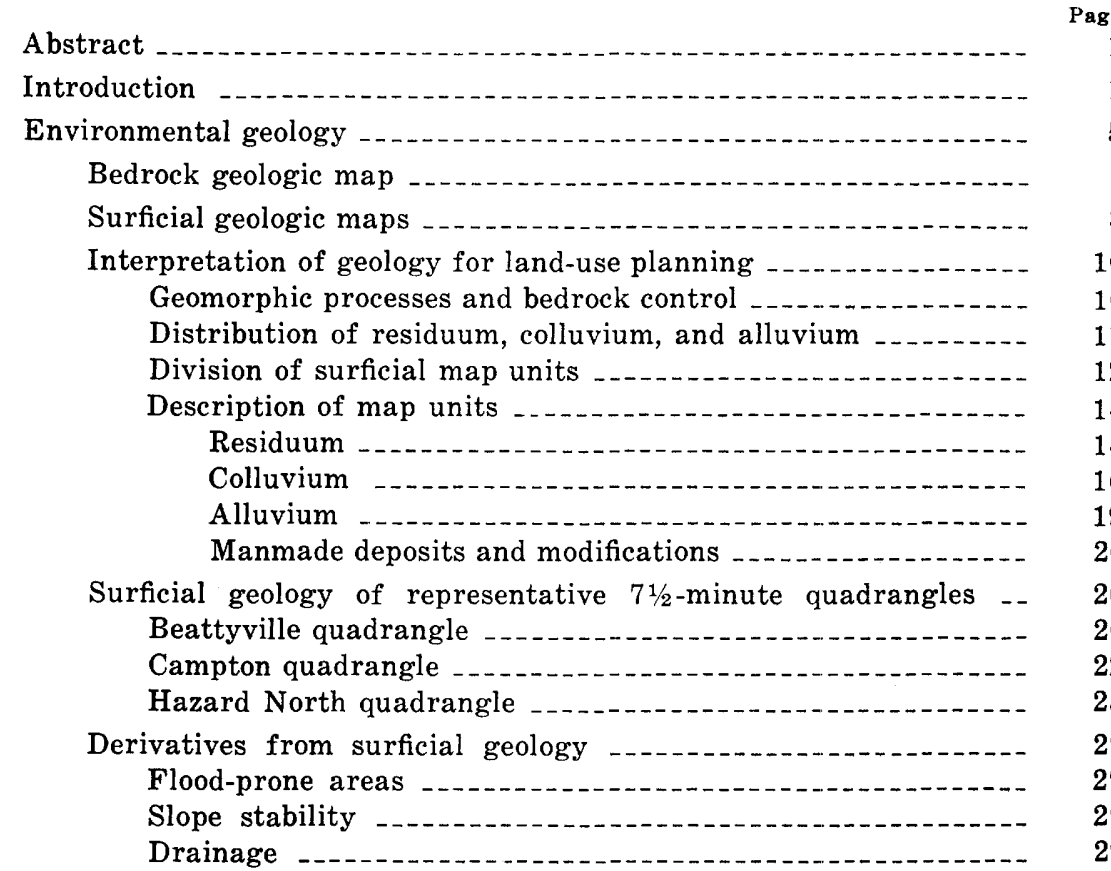

Resources _._.

Mineral-fuels maps _._. 34

Coal _.. 34

Oil and gas .

Water-resources maps _._. 37

Effects of geology and land use on water quality and availability

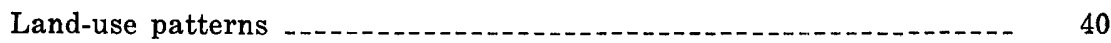

Land-use map ......... 40

Relationship of map to geology and resources -.............. 40

Historical perspective -................ 42

Summary and conclusions _..._.

Glossary of terms as used in this report .

References cited _... 49 


\section{ILLUSTRATIONS}

Figure 1. Index map showing location of Kentucky River Area Development District

2. Generalized cross section of Cumberland Plateau

Page

3. Block diagram showing typical distribution of surficial materials on ridgetops, slopes, and valley bottoms

4. Hill-slope profile formed on siltstone and shale

5. Hill-slope profile controlled by sandstone cap

6. Block diagram and generalized cross section showing surficial geology of a meander bend along South Fork of Kentucky River

7. Block diagram and generalized cross section showing relationship of surficial deposits associated with an abandoned meander bend

8. Graph showing relationship between porosity and thickness of surficial materials and the effects of these variables on ground-water storage

9. Graphs showing relationship between permeability and slope for different surficial materials and the effects of these variables on ground water

10. Graphs showing relationships among thickness of coal beds, number of coal beds, and thickness of exposed stratigraphic section

\section{TABLES}

TABLE 1. Residuum and colluvium as indicators of process intensity

2. Alluvium as an indicator of magnitude and frequency of floods 


\section{Understanding Natural Systems- A Perspective for Land-Use Planning in Appalachian Kentucky}

By WAYNE L. NEWELL

G E O L O G I C A L S U R V E Y B U L L E T I N 1438

Bedrock control of geomorphic processes;

a guide to opportunities

and limitations for the use

of rugged terrain

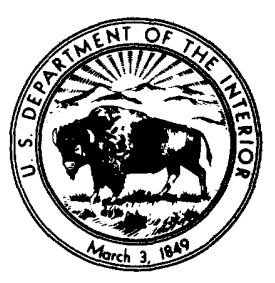




\title{
UNDERSTANDING NATURAL SYSTEMS-A PERSPECTIVE FOR LAND-USE PLANNING IN APPALACHIAN KENTUCKY
}

\author{
By Wayne L. Newei.l.
}

\section{ABSTRACT}

An eight-county area at the headwaters of the Kentucky River has been designated the Kentucky River Area Development District (KRADD) by the Appalachian Regional Commission. The objective of the project described in this report has been to provide materials to KRADD planners in a format and containing terminology usable by local people untrained in earth science.

Experimental maps (not included in this report) have been prepared largely from preexisting data. Time and cost limitations required a regional analysis as well as somewhat more detailed examples of selected localities. Most of the maps produced to meet these needs show the abundance and distribution of naturally occurring materials and the areas affected by various geomorphic processes. Three types of maps, showing current land use, slope, and flood-prone areas, present both basic and derived data directly applicable to specific land-use decisions. Basic map information on quality and quantity of surface and ground water, bedrock and surficial geology, and mineral fuels can be interpreted for a wide variety of current and potential uses. Texts accompanying the maps explain bedrock control of geomorphic processes, distribution and significance of surficial deposits, and hydrologic characteristics of the intricately dissected eastern Kentucky terrain. Within this conceptual framework, geomorphic processes and the landscape may be evaluated in humanly significant terms of low to high potential risk, thereby indicating both opportunities and limitations for land use.

\section{INTRODUCTION}

The Kentucky River Area Development District (KRADD) is defined for planning purposes as eight eastern Kentucky counties (Lee, Wolfe, Owsley, Breathitt, Knott, Leslie, Letcher, and Perry). The eight-county area corresponds roughly to the drainage basin of the headwaters of the Kentucky River, excluding the southern headwaters of the South Fork. The district also includes parts of the Red River watershed along the northern half of Wolfe County and a fragment of the headwaters of the Cumberland River in southernmost Letcher County (fig. 1). 


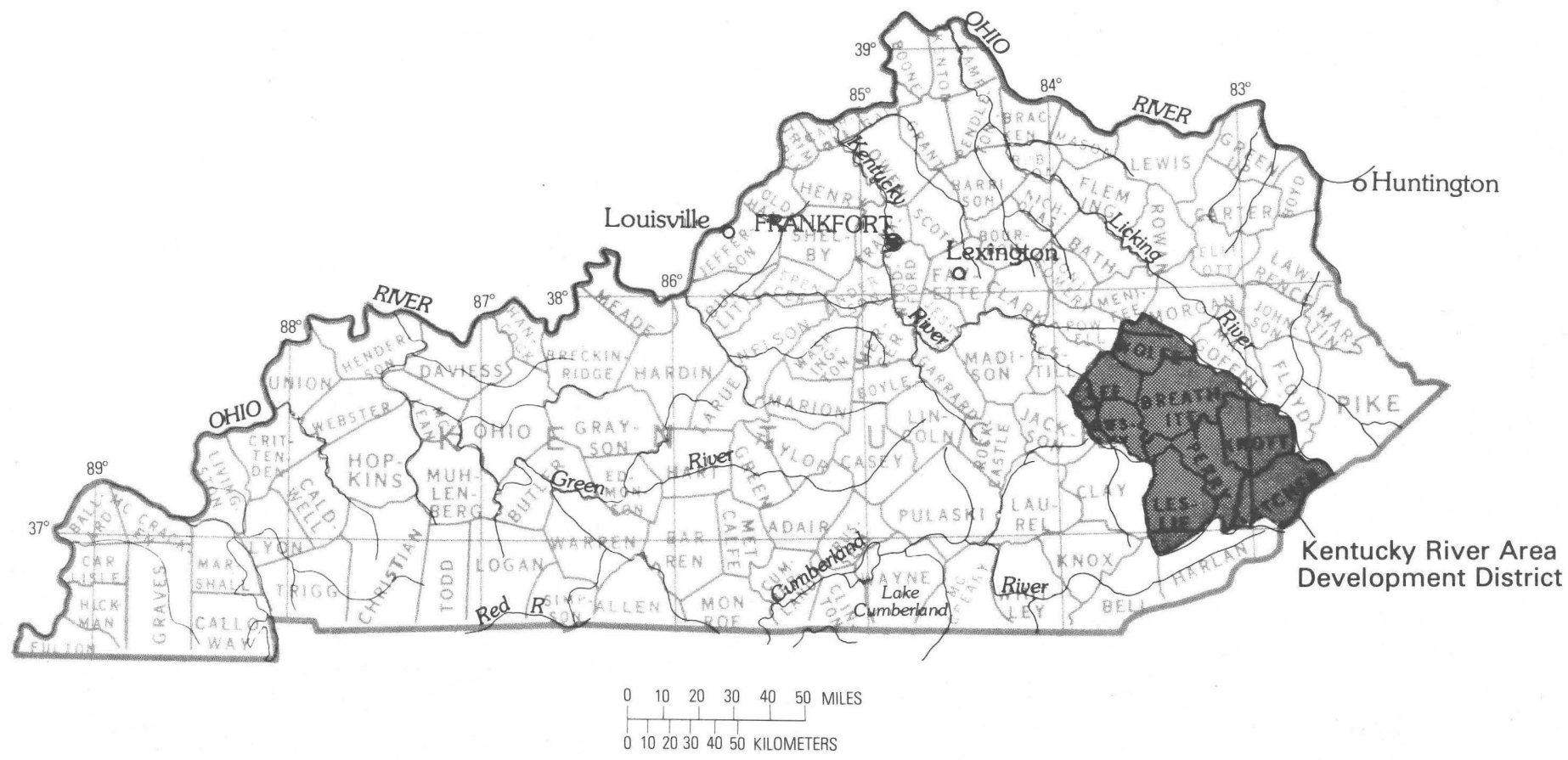

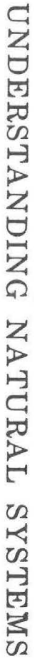

Figure 1.-Location of Kentucky River Area Development District. 
The southeastern border of the Kentucky River area is generally along the crest of Pine Mountain, a prominent northeast-trending ridge. The western edge of the region, characterized by plateaus dissected by canyons of major rivers and their tributaries, is known as the Cumberland Escarpment. Most of the eight-county region is characterized by ridge and ravine topography of the Cumberland Plateau. The sinuous pattern of mountainous ridges and ravines is transected by locally broad meandering valley bottoms of the three forks of the Kentucky River. Access to the region is difficult because of the rugged, intricately dissected topography. Until recently, most travel was confined to valley bottoms, both on the water and along the banks.

Natural systems present both opportunities and limitations for various patterns of land use. Usable information on the physical geology, chemical characteristics, and locally prevailing landshaping processes is necessary to help achieve optimum land use with a minimum of hazard. The economy of the Kentucky River Area Development District and surrounding region is currently derived from available natural resources by both extractive and sustained-yield methods. Home and industrial sites, fuel, timber, and water are in continual demand; therefore, land-use decisions cannot be put off until conventional mapping programs are completed. Although available earth-science information for this area is neither detailed nor uniformly adequate, sufficient data are available to erect a framework from which guidelines can be derived and modified as detailed information becomes available. The objective of the KRADD project is to provide geologic, hydrologic, and land-use maps to area planners through their sponsoring agency, the Appalachian Regional Commission. This information has been compiled from geologic and hydrologic data of the U.S. Geological Survey. Additional supplementary information has been provided where necessary from reconnaissance field studies. The resulting maps have been presented in a format useful to the planning process and to management decisions. These materials are explained and interpreted for the use of people both trained and untrained in earth science. A glossary of the terminology as used herein has been provided at the end of this report.

The first part of this report explains the concepts and facts of environmental geology generally encountered throughout Appalachian Kentucky, concepts necessary for understanding and predicting results of man's interaction with natural systems. Bedrock control of geomorphic processes and resultant surficial materials is fundamental to this discussion. The second part sum- 
marizes the natural resources that attract exploitation in context with regional geology. The third part deals with the distribution of various types of current land use with reference to environmental geologic aspects.

Limitations of time and expense have restricted this research mainly to a small-scale regional experimental treatment. However, larger scale examples, typical of units shown on the regional maps, were selected to portray geologic information in greater detail. These examples are primarily intended as aids in understanding and interpreting the small-scale regional maps. They are not substitutes for detailed geologic, engineering, or geophysical investigations of specific problems, which commonly require detailed site studies by qualified professional personnel.

Two perspectives are currently available to the makers and users of maps for land-use planning. One common approach to the need for planning materials is to make interpretive maps from available basic data. Interpretive maps show the suitability of various types of terrain and bedrock for currently viable uses. Useful as these maps are for immediate needs, they may not wear well, becoming obsolete either when new data are acquired, legal constraints are invoked, or when land uses change. With minor exceptions, this approach has not been used in the production of maps for the Kentucky River Area Development District.

The approach used in preparing geologic information for KRADD adopts the perspective of presenting basic data in a format that can be continually updated and interpreted by planners for changing land uses. To achieve the unlimited flexibility that is possible through this approach, the planner must be supplied not only with the basic data but also with the conceptual tools for interpretation.

The maps prepared for the Kentucky River area, which are generally biased towards an interpretation of suitability for use, included slope maps, flood-prone-area maps, and experimental derivative maps based on the surficial geology of a $71 / 2$-minute quadrangle. The current land-use map is actually a basic-data base; suitability for specific use is not implied. However, the map aids the discussion of the other use-oriented materials because it shows the relationship between some uses and the geology. It too will become obsolete when land uses change.

All other maps for KRADD present two types of information: (1) The spatial distribution and abundance of various natural resources and (2) the identification of geomorphic processes operating through dynamic natural systems. Within the framework 
of bedrock and surficial materials and the processes at work creating landscapes from them, a land user can structure his philosophy and activities either in harmony or at variance with natural systems. Economic analysis may suggest that a user might risk disaster to reap an immediate profit, or he may choose a less risky course, commonly offering a higher sustained profit, a long-term yield, and little or no damage to the environment.

\section{ENVIRONMENTAL GEOLOGY}

Geologic materials for planning include information on bedrock and surficial geology and on the availability and quality of water. Because man uses fuels and building materials derived from bedrock and surficial materials, the occurrence and abundance of these resources is an integral inescapable factor in rational landuse planning. An understanding of the bedrock geology is fundamental to all other geologic and water-related information and natural-systems concepts. Surficial materials are derived by weathering processes operating on bedrock. The resistance or vulnerability to weathering of different rock types is manifested by the materials and terrain produced and, ultimately, in the patterns of runoff production and quality of surface water from various watersheds and in the rate of recharge of ground water and quality of water in deep aquifers.

\section{BEDROCK GEOLOGIC MAP}

A bedrock geologic map of the Kentucky River area (Newell and Rice, 1977a) was compiled largely from preexisting published and unpublished data available to the U.S. Geological Survey. Types of information used to compile this map include records of diamond drill holes, records of rock types along mountain roads where extensive vertical sequences are exposed, and composite records from published data (U.S. Geological Survey Geologic Quadrangle and Coal Investigations maps and Kentucky Geological Survey county maps). Because of the many scales, dates, and sources, the compiled information varies in quality; however, it is adequate to show the gross regional variations of rock types exposed throughout the Kentucky River area. Users interested in greater detail of bedrock geology are advised to consult the coverage provided by the series of $71 \frac{1}{2}$-minute U.S. Geological Survey Geologic Quadrangle maps now nearing completion for the entire State of Kentucky.

Customarily, geologic maps present the spatial distribution of various rock types and an interpretation of the origin and history 
of the rocks. An emphasis on historical geologic interpretation may obscure the fundamental utility of the essential basic data for planning purposes. Thus, the Kentucky River area bedrock map presents basic geologic data essential to planning needs in a form that emphasizes the occurrence of various rock types and facilitates an understanding of bedrock control on land-forming processes and on the surficial materials derived from their interaction. Those interested in an historical interpretation of the bedrock foundation of the mountains and valleys of eastern Kentucky are urged to refer to the published materials from which this map was derived. The map fully identifies the sources of this material.

Three types of bedrock information are shown: Outcrop pattern of lithologically distinctive formations; percentage of sandstone beds in vertical sections of the Breathitt Formation; and average vertical thicknesses of rocks exposed from streambeds to ridgetops.

The outcrop patterns of limestone, pebbly quartzose sandstone, and shale are limited to two localities in KRADD. One occurrence of these materials is at the edge of the Cumberland Escarpment in Wolfe, Lee, and Owsley Counties. Outcrop patterns in this area reflect the many sinuous canyons cut by the Kentucky River, Red River, and their tributaries as they descend from the Cumberland Plateau. Other mappable outcrops of the same rock types occur along the north face of Pine Mountain where they have been brought to the surface by an extensive overthrust fault. The cross section (fig. 2) shows the distribution of major rock types underlying the Kentucky River area.

The rest of KRADD is underlain by the coal-bearing Breathitt Formation of Pennsylvanian age, which includes beds of sandstone, siltstone, shale, and limited noncommercial occurrences of limestone. The component rock types are heterogeneously mixed and locally discontinuous, making it impossible to map the outcrop patterns of individual beds at a regional scale. However, the regional distribution of rock types within the Breathitt Formation can be shown in terms of the relative abundance of different rock types from place to place. Sandstone and shale constitute all but a few percent of the Breathitt Formation and produce surficial materials that have distinctive environmentally important characteristics. Thus, most of the Breathitt Formation has been divided and mapped according to the relative abundance of sandstone in the total volume of rock exposed above valley bottoms. 


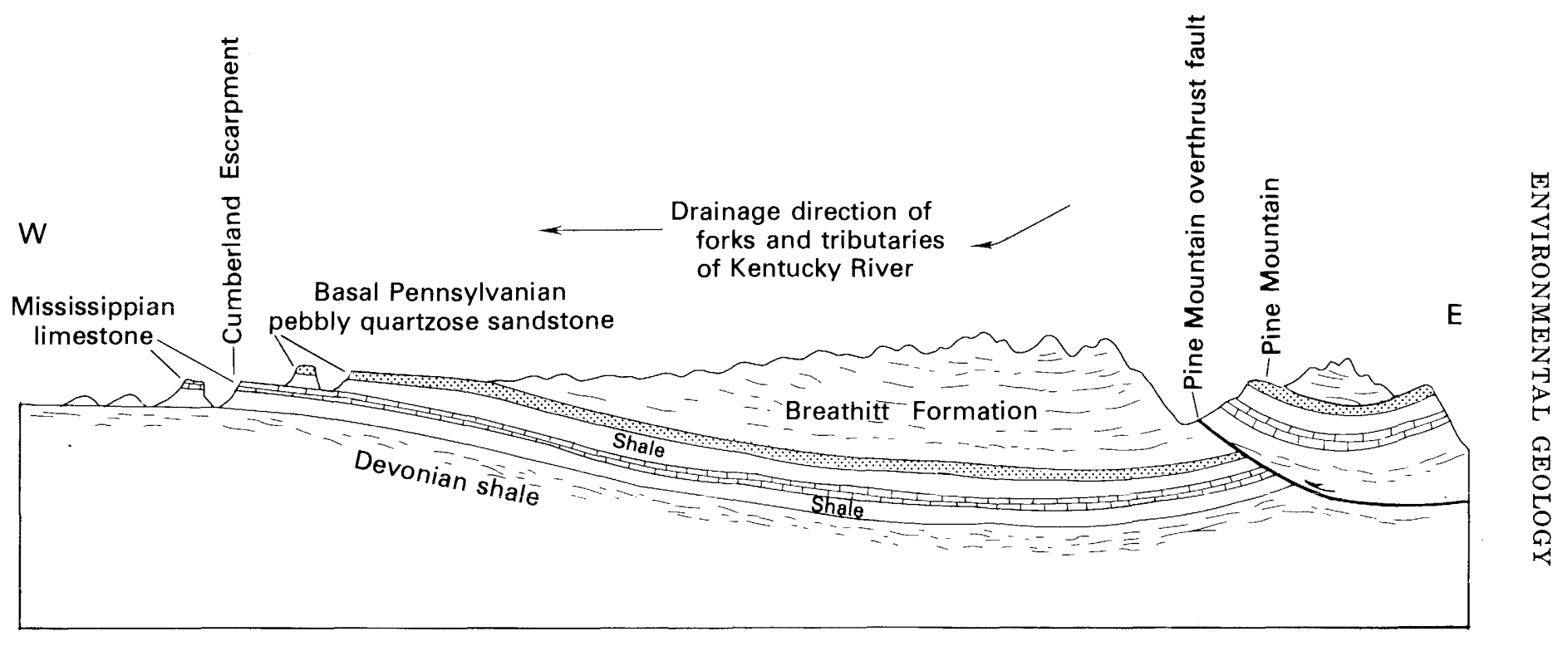

FIGURE 2.-Generalized cross section of Cumberland Plateau. 
The average vertical thickness of rock exposed from streambeds to ridgetops is shown by isopleths of topographic relief. This information was generated by dividing the Kentucky River area map into units of area equal to quarters of $71 / 2-$ minute quadrangles. The topographic relief was calculated from the lowest and highest points in each unit, was then plotted on unit centers, and contoured at $100-$ foot $(30-\mathrm{m})$ intervals. Equipped with this information and with knowledge of the relative abundance of sandstone and shale, the map user can observe that an area of interest is characterized by a particular thickness of bedrock (above drainage) that is predominantly sandstone, shale, or an approximately equal mixture of both. It is here emphasized that this map has been prepared solely as a regional representation of bedrock exposed at the surface. The outcrop patterns and relative abundance of sandstone and shale in the Breathitt Formation are intended to indicate the type of bedrock from which surficial deposits and residuum have been derived. With the exception of faults and outcrop patterns of distinctive lithologies, stratigraphic and structural information are not incorporated in this map and cannot be interpreted from it. Users in need of this information must refer to the published source materials cited on the map.

\section{SURFICIAL GEOLOGIC MAPS}

Four maps (Newell, 1977a, b) show the distribution of surficial materials, their physical characteristics, and the natural system of land-shaping processes that they define. The maps include a regional-scale $(1: 125,000)$ overview of surficial geology (1977a) and three 71/2-minute-quadrangle $(1: 24,000)$ reconnaissance maps (1977b) which show greater detail.

At the regional scale, all land surfaces in the Kentucky River area have been classified and mapped in one of three units that reflect three natural processes collectively operating as a dynamic land-shaping system. The three units are residuum, colluvium, and alluvium. Residuum is a product of chemical weathering of the bedrock and consists of insoluble minerals and rock fragments. It generally is found on ridgetops and flat uplands. Colluvium includes angular unsorted materials transported down steep slopes by creep, slumping, mudflows, and landslides (mass movement). Alluvium occurs on flood plains and valley-bottom terraces; deposits consist of materials derived from colluvium and residuum that have been transported, rounded, and sorted by streams and rivers. Figure 3 shows the distribution of surface materials resulting from the interaction of weathering, mass movement, and 


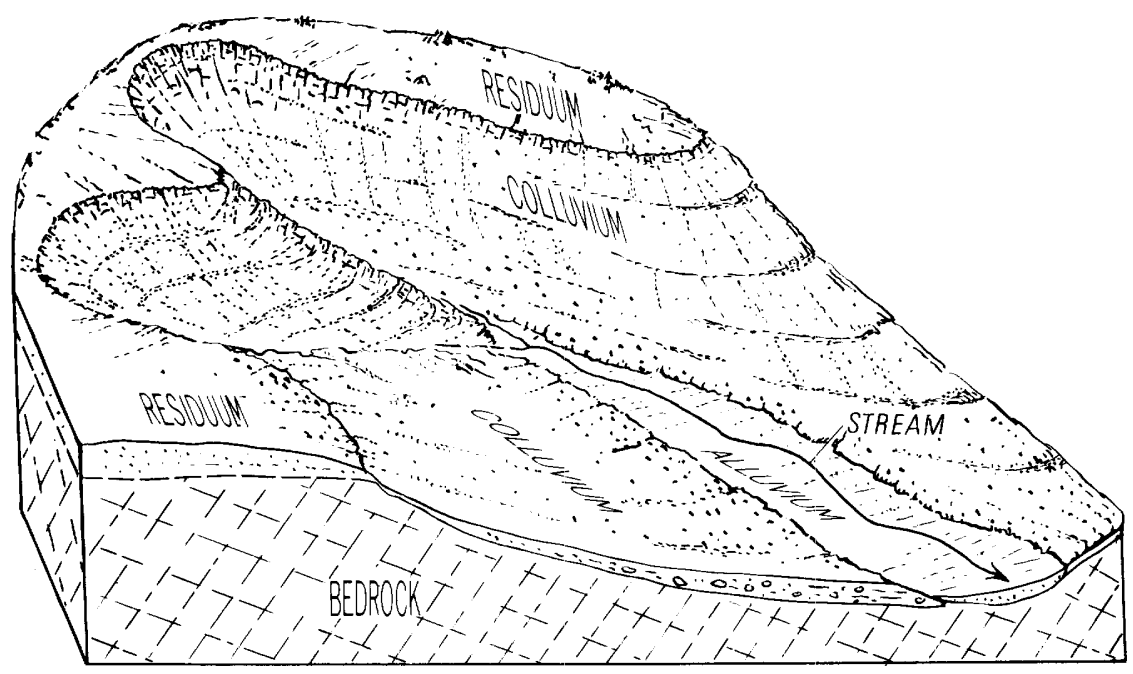

Figure 3.-Block diagram showing typical distribution of surficial materials on ridgetops, slopes, and valley bottoms.

stream processes on a typical hill-slope profile. The influence of bedrock source materials on the characteristics of alluvium, colluvium, and residuum and on their physical properties and surficial expression, is explained in the text accompanying the map.

The three $71 / 2$-minute quadrangles, the Beattyville, Campton, and Hazard North, were selected to illustrate the surficial geology of typical Kentucky River area environments. The Beattyville quadrangle incorporates examples of nearly all types of terrain and bedrock found in the Kentucky River area. The Campton and Hazard North quadrangles include parts of the State Highway 15 development corridor in addition to typical landforms.

Although some typical limestone terrain was studied by the author during the present field investigations and has been discussed at the regional scale, a detailed map showing areas of surficial materials derived from limestone has not been produced because significant deposits and residuum are found mostly within the Daniel Boone National Forest. Use of National Forest land is outside the responsibility of KRADD planners.

Where applicable, each of the three basic map units, residuum, colluvium, and alluvium, has been subdivided to show not only the areal distribution of different materials but also the relative effectiveness of the processes that produced them.

At the $71 / 2$-minute scale, a fourth basic map unit-manmade deposits-has been added and subdivided. This unit is most ex- 
tensive in the Hazard North quadrangle in the form of abundant mine-spoil banks. Extensive areas of manmade deposits from mining and quarrying are not included on the regional surficial geology map because this information is presented on the current land-use map (U.S. Geol. Survey, 1975).

\section{INTERPRETATION OF GEOLOGY FOR LAND-USE PLANNING}

\section{GEOMORPHIC PROCESSES AND BEDROCK CONTROL}

The regional surficial map of the entire Kentucky River area (Newell, 1977a) and the three quadrangle maps (Newell, 1977b) portray the geology of surficial materials as a key to understanding the geomorphic processes that function together as integral parts of a natural system, modifying and shaping the landscape. The landscape is not static; it is the foundation of a dynamic environment. The definition of size, shape, and distribution of surficial deposits and residual materials reveals areas over which different processes are relatively most effective or particularly intense and frequent. The relationship between processes and landforms defined by surficial geology provides an ever-current perspective on the opportunities and limitations found within all possible environmental situations.

Geomorphic processes with few exceptions are inextricably related to the movement of water, ice, and air; these materials are driven by gravity and solar radiation through the atmosphere, across the face of the land, into the oceans, and back into the atmosphere again through endless and myriad paths collectively known as the hydrologic cycle. In eastern Kentucky, under humid climatic conditions, three water-related processes are at workchemical weathering, mass movement, and streamflow. These processes respectively weather the bedrock, move weathered broken rock materials down slopes, and transport them out of watersheds down the streams and rivers, producing residuum, colluvium, and alluvium (see p. 8 ). Each type of surficial material has resulted from a process that is significant to the human environment. Residuum underlies well-drained, nearly level surfaces. Colluvium is the product of landslides, mudflows, and other forms of slope failure. Alluvium is found, for the most part, in areas that experience flooding. Each of these distinctive materials is defined as a map unit, and its environmental significance is discussed in the explanation for the surficial geologic maps (Newell, 1977a, b).

All land surfaces in the Kentucky River area can be mapped according to the erosional features, deposits, and nontransported 
remnants that occur upon them. Thus, a map of surficial geology shows not only the distribution of distinctive materials that have different physical properties but also the erosional and depositional history.

Bedrock, the ultimate source of all surficial materials, is, in this part of Kentucky, a highly variable assemblage of sandstone, siltstone, shale, limestone, and coal. Some of these rock types are porous, others soluble, and other disintegrate readily. The interaction between the various rock types and processes ultimately controls the extent and depth of weathering, the size and shape of debris moving down slopes, valley width, average particle size, and depth of alluvium.

The distribution of weathered bedrock, materials in transport on hill slopes, and alluvium-each material well or poorly drained -ultimately controls the water budget of Kentucky River area watersheds. Runoff, storage, and base flow are all affected by the steepness of the slopes and by the porosity of the soils and unconsolidated materials. The control of bedrock on the physical characteristics of residuum, colluvium, and alluvium is discussed on the regional surficial geologic map (Newell, 1977a).

\section{DISTRIBUTION OF RESIDIUUM, COLLUVIUM. AND ALLUVIUM}

The regional surficial geologic map (Newell, 1977a) shows that residuum is most extensive along the northwestern edge of Kentucky River area, where most of the shaly lower part of the Breathitt Formation has been eroded away, leaving nearly level to gently rolling surfaces on top of resistant sandstone ledges. Isolated patches of residuum large enough to map are present near Whitesburg and Booneville. Inaccessible mountaintop patches such as these are common where weak soft rocks-shale, coal, and thin limestone-are perched above a resistant sandstone bed. Mantles of thin residuum, limited to a few acres, repose on many ridgetops throughout the Kentucky River area but are too small to show at regional scale.

Colluvium is the most extensive map unit of the entire Kentucky River area. Most of the terrain mapped as colluvium at scale 1:125,000 includes small isolated patches of very thin residuum on rounded ridge crests and spurs. It also includes thin sinuous deposits of alluvium along the bottoms of most valleys where the volume of stream runoff is sufficient to sort valleybottom colluvium. Comparison of the regional surficial geologic map with the regional bedrock map (Newell and Rice, 1977a) shows the generalized lithology of parent rocks. Sandstone ledges 
support steep slopes. The colluvium derived from sandstone consists of moderately well drained sandy material having blocky rubbly slopes. Less resistant rocks, such as shale, generally do not support steep slopes. Colluvium that covers slopes developed from weathered shale is commonly thin, clayey, and poorly drained.

Alluvium covers the smallest total area of the region. However, historically, it has been and still remains the most significant surficial deposit because it underlies continuous gentle slopes providing access for various forms of transportation into the interior of the Kentucky River headwaters area. It is also fertile, easily tilled land for the most part. The primary limitation to use of the alluvial bottoms is their susceptibility to flooding, which is documented on the flood-prone-area map (Davis, 1977b). During early days of river commerce, floods were used to advantage in the transportation of $\log _{s}$ and rafts out of the interior to navigation downstream. Historical writings document the widespread economic use of floods (Verhoef, 1917). At present, however, floods are a hindrance and not a help in most of man's attempts to use the bottomlands.

Alluvial bottom lands, although sandy and well drained, are generally narrow and confined between rugged hills in areas underlain by predominantly resistant sandstone bedrock. Where shale is more common, as in the South Fork Valley, the bottom lands may be as much as 1 mile $(1.6 \mathrm{~km})$ wide and may have multiple terraces bounded alternately by gentle hill slopes and steep meander-bend escarpments. Lower frequently flooded river terraces are poorly drained, whereas higher trraces, having been weathered, are better drained. Several large abandoned meanderbend bottom lands, well above present flood-prone areas, are found in the area of predominantly shaly bedrock. One such large bottom land east of Beattyville is mapped in detail on the Beattyville quadrangle map (Newell 1977b). Other smaller examples are found along all the major river valleys of the Kentucky River area.

\section{DIVISION OF SURFICIAL MAP UNITS}

Distribution of surficial materials cannot be shown in detail on the regional scale map; thus this map is of limited value for interpretations. Detailed information is presented on the Beattyville, Campton, and Hazard North $71 / 2$-minute quadrangle maps (Newell 1977b). These maps provide sufficient detail to interpret 
the effect on the landscape of natural processes in typical local environments throughout the region.

The three basic map units of the regional surficial geologic map-residuum, colluvium, and alluvium-are divisible on $1: 24,000$-scale maps into units that variously reflect the intensity and frequency of occurrence of the three causative geomorphic processes. The subdivided map units can be ranked according to the relative intensity or magnitude and frequency of the causative process. Tables 1 and 2 illustrate this concept. As shown by table

TABLE 1.-Residuum and colluvium as indicators of process intensity

[Thickness of surficial material underlying a slope is a function of an incrementally accumulating volume minus increments lost through erosion. On much of the landscape, erosion and accumulation are balanced. At localities underlain by thick residuum, the effect of chemical weathering is at a maximum, and erosion (largely through mass movement) is at a minimum. Conversely, at localities underlain by thin discontinuous colluvium, mass movement is at a maximum and all other processes are at a minimum /

\begin{tabular}{|c|c|c|c|}
\hline Process & $\begin{array}{l}\text { Volume eroding } \\
\text { exceeds volume } \\
\text { accumulating }\end{array}$ & $\begin{array}{l}\text { Volume accumulating } \\
\text { equals volume eroding }\end{array}$ & $\begin{array}{l}\text { Volume accumulating } \\
\text { exceeds volume eroding }\end{array}$ \\
\hline $\begin{array}{l}\text { Chemical } \\
\text { weathering. }\end{array}$ & No residuum & Thin residuum & Thick residuum. \\
\hline $\begin{array}{l}\text { Mass } \\
\text { movement. }\end{array}$ & $\begin{array}{l}\text { Thin discontinuous } \\
\text { colluvium. }\end{array}$ & $\begin{array}{l}\text { Thin continuous } \\
\text { colluvium. }\end{array}$ & Thick colluvium. \\
\hline
\end{tabular}

TABLE 2.-Alluvium as an indicator of magnitude and frequency of floods [Relative height of alluvial deposits above stream channels reflects the recurrence interval and size of floods]

\begin{tabular}{lcccc}
\hline Process & $\begin{array}{c}\text { Frequently flooded, } \\
\text { exoded and deposited }\end{array}$ & $\begin{array}{c}\text { Less frequently flooded } \\
(10-100-\mathrm{yr} \text { intervals })\end{array}$ & Flooding unlikely \\
\hline Streamflow & $\ldots-.-$ & $\begin{array}{c}\text { Channel and flood- } \\
\text { plain alluvium. }\end{array}$ & $\begin{array}{c}\text { Low-level terrace } \\
\text { alluvium. }\end{array}$ & $\begin{array}{c}\text { High-level terrace } \\
\text { alluvium. }\end{array}$ \\
\hline
\end{tabular}

2 , alluvium reflects the recurrence of moderate to very large flood stages. The relative effectiveness or intensity of chemical weathering and mass movement is best documented by the thickness of residuum and colluvium (table 1 ). The most intensive chemical weathering is documented by thick accumulations of residuum, whereas thin colluvium and exposed bedrock on steep slopes indicate the most active mass movement. Undoubtedly, some variations in thickness of both residuum and colluvium are a function of bedrock type. The same processes operating on sandstone and shale, for example, will produce different thicknesses of residuum, different slope angles, and, consequently, different thicknesses and 
composition of colluvium. The map-unit ranking system of tables 1 and 2 may be overly generalized unless surficial materials developed from uniform rock types are compared.

Although a generalization, the tables do indicate that variations in process intensity, magnitude, and frequency of activity can be depicted from place to place by the areal distribution of the products. If process intensity is understood as a variable dependent on rock type, topographic aspect, and climate, then the magnitude of opportunities and the limitations that the process represents can be perceived and applied to land use. By combining different surficial map units according to the guidelines of tables 1 and 2, derivative maps can be rapidly produced showing floodprone areas (a function of stream flow), slope stability (a function of mass movement), or permeability (a function of weathering and rock type.) As an example, a slope-stability map (Newell, 1977c) has been prepared as a derivative of the surficial geology of the Beattyville quadrangle. It compares favorably with a slope map of that quadrangle (U.S. Geol. Survey, 1974a). A floodprone-area map (Davis, 1976b) produced by hydrologic methods also compares favorably with the distribution of alluvium.

\section{DESCRIPTION OF MAP UNITS}

\section{RESIDUUM}

Residuum, where mappable, has been divided into two units, thick residuum and thin residuum.

Thick residuum (unit $\mathbf{r}_{1}$ ), for the most part, underlies level to gently sloping land on broad upland benches supported by sandstone beds of the Lee and Breathitt Formations. Other areas of thick residuum are on ridge crests and broad convex-upward slopes underlain by interbedded siltstone, shale, and thin beds of sandstone. Thick residuum results where the rate of accumulation of weathered products exceeds the rate of their erosion. The rate of weathering is manifested in a profile that becomes deeper more rapidly than material is eroded from the surface by mass movement.

Areas of deep weathering on low-angle slopes are environmentally significant because the weathering horizon is usually highly permeable and easily excavated. Both the permeable weathered horizon and steeper outcrops of the parent bedrock are groundwater recharge areas for important sandstone aquifers.

Thin residuum (unit $r_{2}$ ) is much more extensively mapped. It is found on generally convex-upward hill slopes, ridgetops, and 
spurs. Chemical weathering that produces the thin residuum probably acts at a rate similar to that which prevails on the nearly level occurrences of thick residuum. The underlying siltstone and shale, however, are more susceptible to erosion, and steeper convex slopes result. On the average, over a long period, the volume of material removed probably approximates the volume of new weathered material produced on the convex slopes. The steepness, convexity, or concavity of the slopes is a function of the weathering characteristics of the bedrock. Commonly, sandstone beds produce steep slopes and cliffs. Outcrops of sandstone are more resistant than shale or siltstone, possibly because at or near a steep surface, the porous sandstone absorbs water and passes it through quickly, and very little leaching of the cement and grains takes place. However, backslope from the outcrop, because of the permeability and saturation of the rock and the movement of water, the sandstone is generally leached and friable, characteristics that produce thick residuum.

Siltstone, shale, and thin interbedded sandstone are more susceptible to erosion and mass movement than is sandstone. They do not crop out as resistant ledges and level uplands but form a generally uniform slope. The upper part of the slope is convex upward and is the area of weathering and removal of material. The material derived from the convex part accumulates at the base of the slope where the profile is concave upward. Figures 4 and $\mathbf{5}$ show this configuration and typical hill-slope profile underlying a cap of thick residuum.

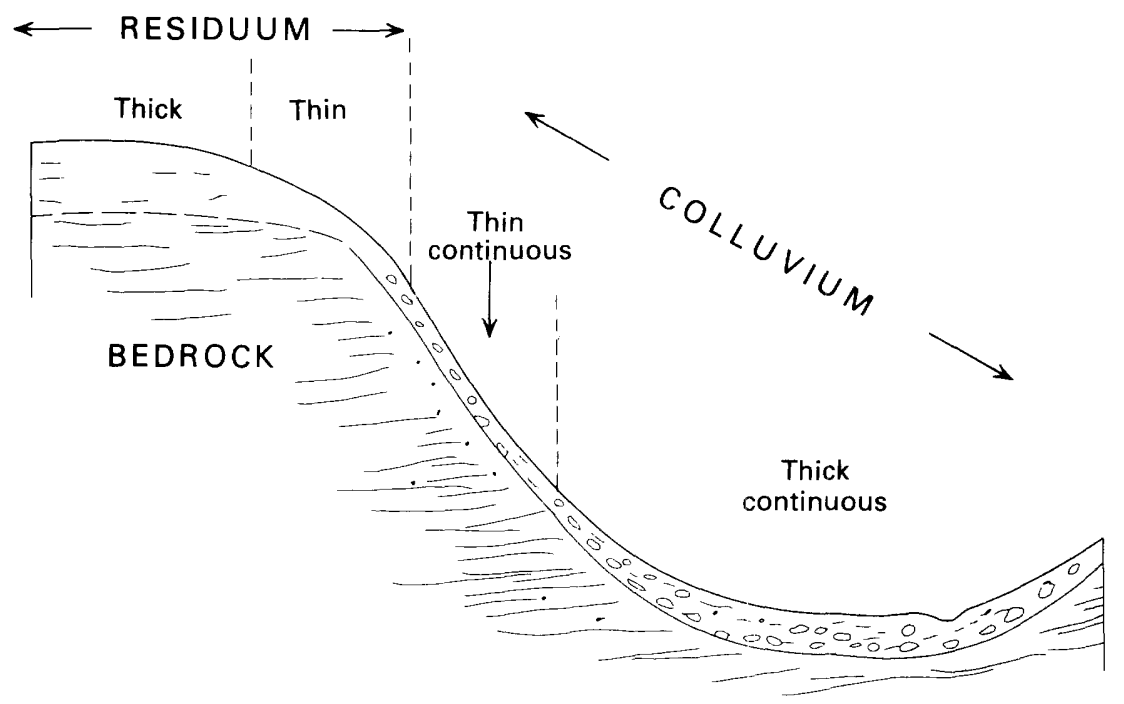

Figure 4.-Hill-slope profile formed on siltstone and shale. 


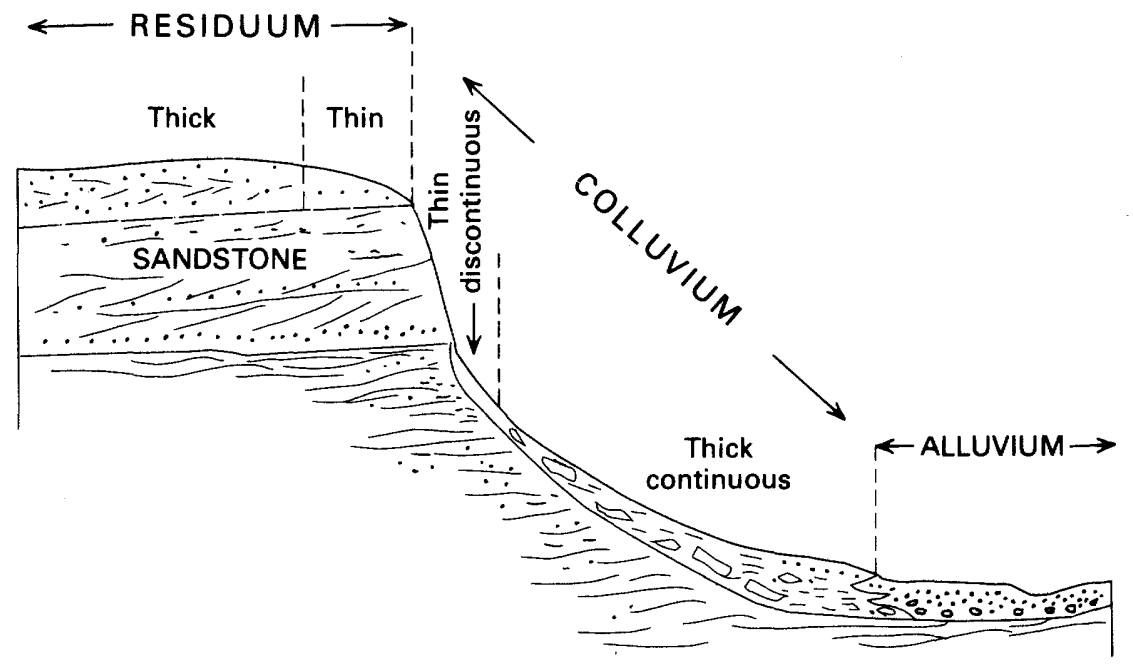

FIGURE 5.-Hill-slope profile controlled by sandstone cap.

COLIUVIUM

Colluvium has been divided into three units that indicate the relative volumes of weathered materials and rock debris moving downslope and accumulating on slopes. The median unit, thin continuous colluvium (unit $c_{2}$ ), represents a balance between amount of material eroded and deposited on a slope and is the most extensive of the three. The other two units, $c_{1}$ and $c_{3}$, end members of the mass-movement and accumulation system, are limited in occurrence and commonly are juxtaposed. Usually, areas where intensive mass movement $\left(c_{1}\right)$ takes place are the source areas for localities of thick accumulations of colluvium $\left(c_{3}\right)$. As seen on the map, such areas of intensive mass movement are, for the most part, along entrenched river meanders. Figure 6 shows a typical meander-bend locality that has discontinuous colluvium $\left(c_{1}\right)$ on the steep upper slopes. Bedrock buttresses alternate with troughs filled with thin discontinuous colluvium. The troughs feed into the thick wedge of accumulating colluvium. The surface of thick colluvium $\left(c_{3}\right)$ is graded to the angle of repose of the material, and the toe of the wedge of colluvium forms the bank of the stream. Stream erosion during each flood removes material from the toe of the wedge, and more slides down from above to replace it; thus, a dynamic system is created.

If the river should abandon the meander bend for a different course, then the dynamic mass-movement system would no longer be in equilibrium. Instead, a new equilibrium is attained as the 


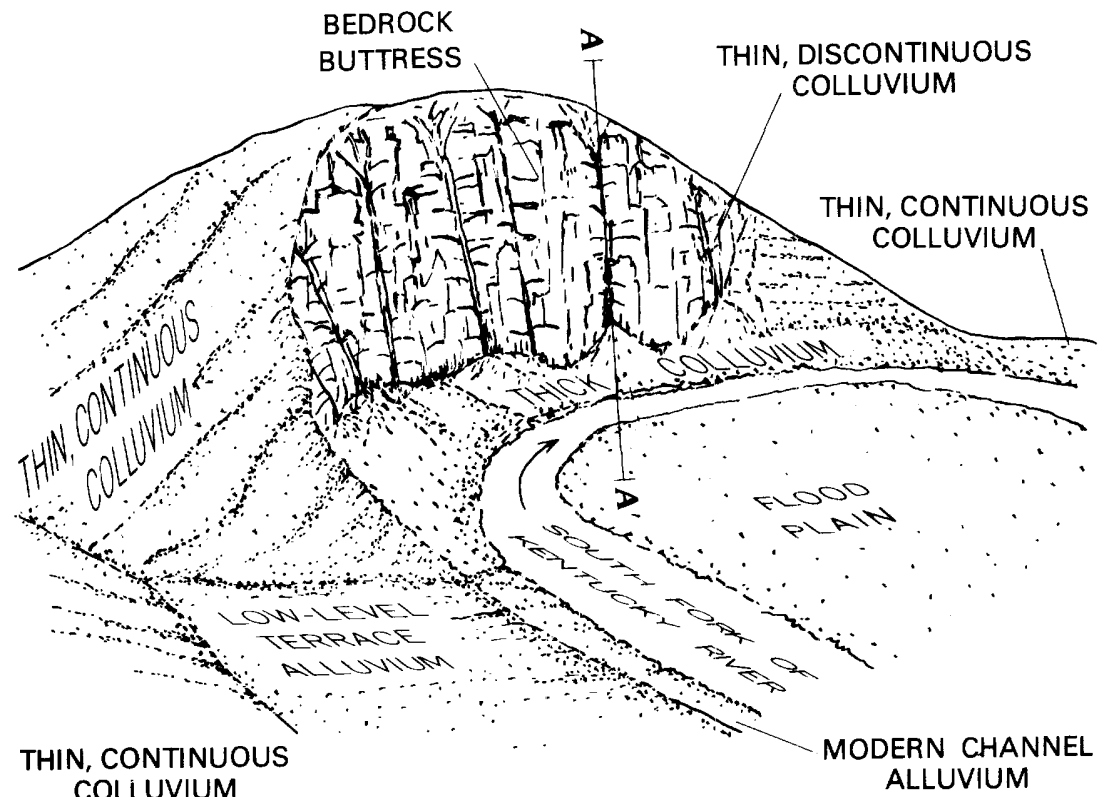

A

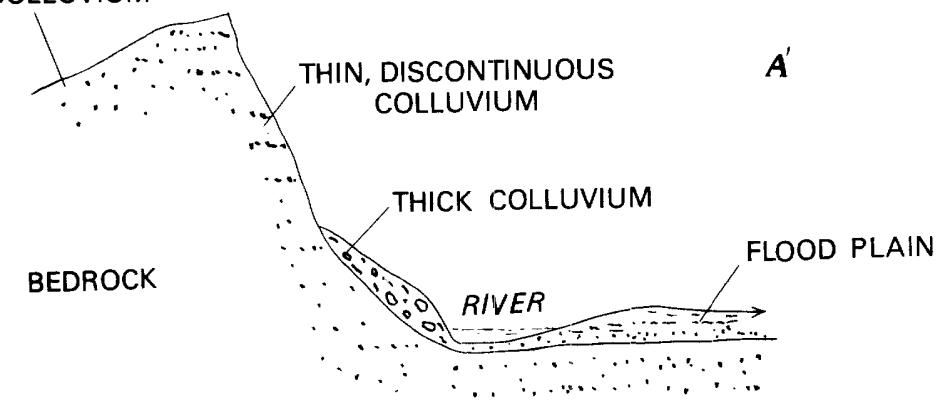

Figure 6.-Block diagram and generalized cross section showing surficial geology of a meander bend along South Fork of Kentucky River.

thick colluvium continues to accumulate and the deposit blankets old river-channel sediments. Bedrock outcrops gradually waste back and the troughs between them fill with colluvium, until the slope becomes more stable and is covered with thin continuous colluvium $\left(c_{2}\right)$. Figure 7 shows this situation. The use of land under these conditions is contingent upon the maintenance of the naturally graded slope of thick colluvium at the base. If the toe of the slope is excavated, then the dynamic mass-movement system will be reactivated.

Thick colluvium $\left(c_{3}\right)$ is also found at the mouths of some hollows and along the bottoms of small valleys where the stream runoff is not great enough to sort, carry, and redeposit alluvium derived 


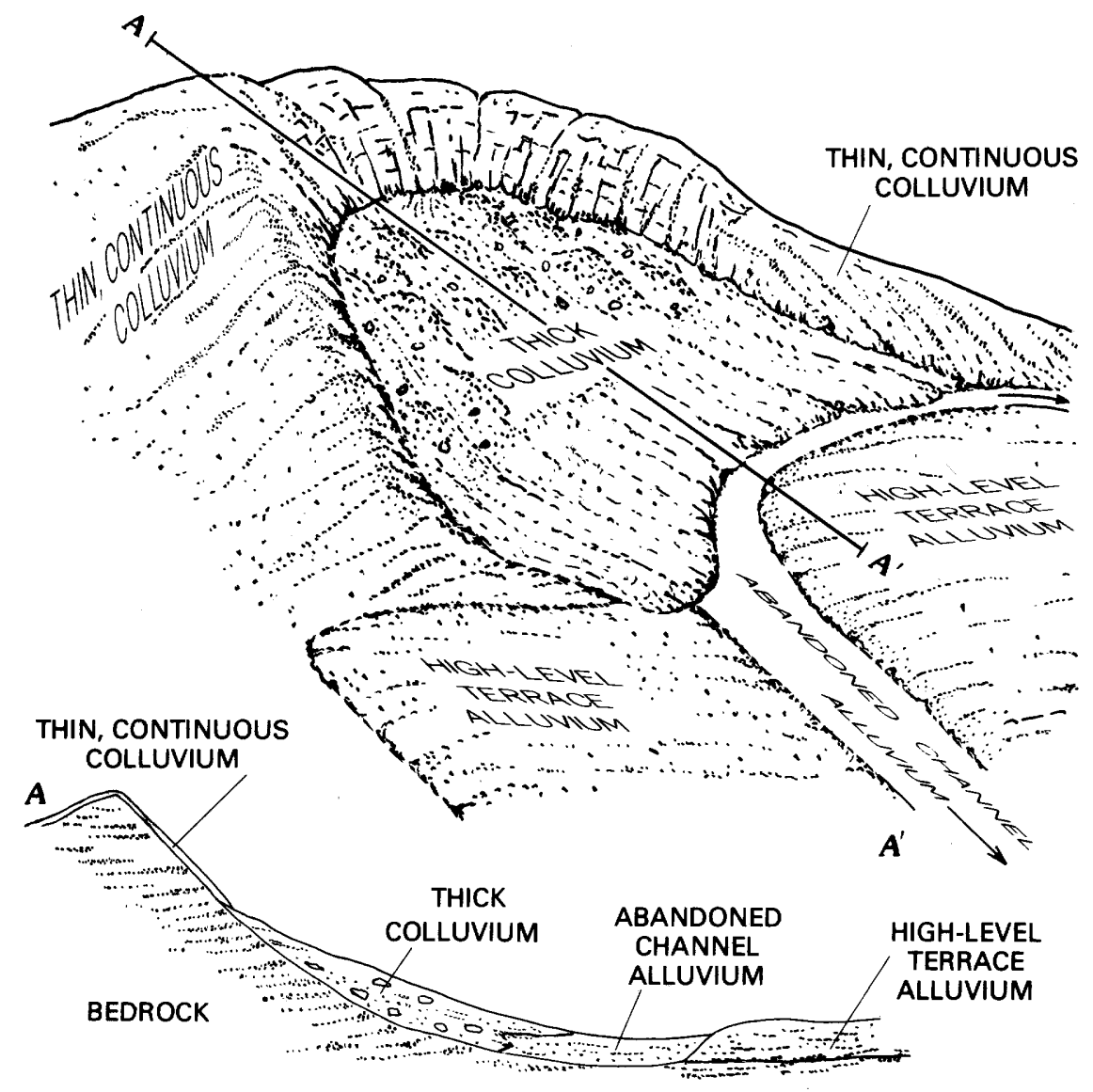

FigURE 7.-Block diagram and generalized cross section showing relationship of surficial deposits associated with an abandoned meander bend.

from the colluvium. Some deposits of thick colluvium are the result of individual intense storms, which produced landslides and debris fans at the bases of slopes and the mouths of tributary streams.

As described on the regional surficial geologic map of the Kentucky River area (Newell, 1977a), shale and sandstone each produce colluvium that has distinctive drainage characteristics. Shale colluvium is nearly impermeable, whereas sandstone colluvium is permeable. Because these materials are moved down mountainsides, shale colluvium, for example, commonly rests on sandstone bedrock. Colluvium resting on a sandstone bench may be comparatively dry and stable in contrast to saturated colluvium that overlies shale and coal beds. Complications may arise where the 
lower slopes of saturated colluvium are undercut, either by a stream or by man for a road or building site. Engineering solutions to such problems can be costly and have no guarantee of success. Some sites can only be stabilized by stripping off the colluvium on the slopes above. Other sites may be stabilized by diverting ground water away from hollows-the areas of convergent flow and greatest saturation-across the slopes towards convex slopes that diverge ground-water flow under and through the colluvium.

ALIUVIUM

Mappable variations in sediments-their weathering and erosion-are the criteria for subdividing alluvium. At some localities, modern channel and flood-plain alluvium $\left(a_{1}\right)$, low-level terrace alluvium $\left(a_{2}\right)$, and high-level terrace alluvium $\left(a_{3}\right)$ can be distinguished. By their weathering, erosion, and topographic position, each of these deposits reflects the frequency of flooding at various stage heights.

With the exception of high-level terrace alluvium $\left(a_{3}\right)$, all alluvium is confined to valley bottoms. Because high-level terrace alluvium $\left(\mathrm{a}_{3}\right)$ is mapped as high as 300 feet $(91 \mathrm{~m})$ above modern stream channels, and because it constitutes only limited remnants of earlier valley bottoms, it is interpreted as being much older than deposits on modern valley bottoms. How old these deposits are is difficult to determine, and most attempts are very speculative, but such deposits, being very ancient, must have undergone long periods of weathering, erosion, and soil formation.

Modern channel and flood-plain alluvium $\left(a_{1}\right)$ is frequently flooded. Thus, channel sediments are often eroded and redeposited, and flood plains receive new accumulations of fresh sand, silt, and clay. Steep channel banks are subject to slumping during and after floods. Small coalescing tributary stream valleys contain modest volumes of modern channel and flood-plain alluvium, which generally is less than 10 feet $(3 \mathrm{~m})$ thick. It is produced, for the most part, from colluvium along the valley bottoms.

In broad valleys, the modern channel and flood-plain alluvium $\left(a_{1}\right)$ is usually entrenched in older alluvium underlying low-level terraces. Because the low-level terrace alluvium $\left(a_{2}\right)$ is no longer frequently flooded, it does not commonly include fresh accumulations of sediment. Thus, the older material is more weathered and eroded. 


\section{MANMADE DEPOSITS AND MODIFICATIONS}

Manmade deposits and modifications have been divided according to their associated land use. Although mine spoil (unit s) is basically colluvium and is moved and altered after deposition by the same processes that affect naturally occurring colluvium, it is less weathered and thus more porous because it contains less clay and silt. Mine spoil is generally less well sorted than naturally occurring deposits and is not in equilibrium with the slope from which it has been excavated and upon which it rests. Because these materials are not in equilibrium they will be weathered, moved, and sorted by natural processes until equilibrium slope conditions are reestablished.

Unlike mine spoil, artificial fill (af) of highways, railroads, and sanitary landfills is compacted and graded to low stable slopes. Highway cuts (hc) through mountains expose fresh bedrock, including both resistant sandstone and weak shale. Generally, the roadcuts are terraced and graded to maintain stability while the rocks weather. In contrast, surface-mine high-wall exposures may eventually collapse after weathering and the disintegration of weak rocks.

\section{SURFICIAL GEOLOGY OF REPRESENTATIVE 71/2-MINUTE QUADRANGLES}

\section{BEATTYVILLE QUADRANGLE}

All the physiographic features (except limestone terrain) observable throughout the Kentucky River area are present within the Beattyville quadrangle (Newell, 1977b). The diversity of terrain elements and surficial materials, which reflect areal variations in bedrock composition, facilitates a more complete subdivision of residuum, colluvium, and alluvium than is possible in the other two quadrangles. Along the northern border of the quadrangle are prominent beds of quartzose pebbly sandstone of the Lee Formation. South of the main stem of the Kentucky River and west of the South Fork are more easily weathered sandstone beds, typical of the Breathitt Formation. East of the South Fork and south of the Middle Fork, bedrock is predominantly shale and siltstone.

Extensive nearly level plains and rolling uplands, dissected by precipitous gorges of Kentucky River tributaries, characterize the topography along the northern and western sides of the quadrangle. The plains and uplands are underlain by gently sloping to flat-lying beds of sandstone interbedded with shale. The sandstone beds crop out as steep escarpments along the gorges and valley 
walls of entrenched meanders cut by the North Fork, main stem, and tributaries of the Kentucky River. The South and Middle Forks flow through broad meander-belt lowlands cut in flat-lying shale and siltstone. The three forks are confluent near Beattyville, where the main stem of the river flows westward. The rest of the quadrangle, especially south and east of the South and Middle Forks of the Kentucky River, has typical ridge and ravine topography. The uniform and ubiquitous distribution of shale and siltstone underlying the ridges and ravines is reflected in the distribution of surficial materials on the hill slopes.

Residuum.-Extensive areas of thick residuum (unit $\mathrm{r}_{1}$ ) underlie the plains and rolling uplands that are supported by sandstone beds. Because of the stable nearly level slopes, thick residuum is suitable for agriculture and other uses. Much of the modern road system is built on areas mapped as residuum.

Some localities of thick residuum near the present valleys of the river's three forks include deeply weathered reworked highlevel terrace alluvium that is not mappable as a discrete deposit. Traces of high-level terrace sediments are found west of the South Fork opposite Lower Buffalo and in the northeast corner of the map, north of Airdale.

Thin residuum $\left(r_{2}\right)$ found on most uplands north of the North Fork and west of the South Fork is generally less stable than thick residuum, although it may be relatively stable compared with areas underlain by colluvium.

Colluvium.-Colluvium is probably the most extensive map unit of the quadrangle. Thin continuous colluvium (unit $c_{2}$ ) is found mostly on the hill slopes of the uniform ridge and ravine topography south and east of the Middle and South Forks. Elsewhere, it mantles most slopes between residuum-covered uplands and valley-bottom deposits.

Conspicuous areas of thin discontinuous colluvium $\left(c_{1}\right)$ are present mainly along bluffs of the Kentucky River and its forks. Deposits of thick colluvium $\left(c_{::}\right)$accumulate along the bases of many steep slopes and in some narrow valley bottoms.

Alluvium.-Low-level terrace alluvium (unit $\mathrm{a}_{2}$ ) and modern channel and flood-plain alluvium $\left(a_{1}\right)$ are most extensive along the South Fork and in the area of confluence of the Middle and North Forks. Because of the weak predominantly shaly bedrock, the meandering rivers have cut broad bottom lands with low channel gradients. During floods, much of the bottom lands may be inundated and receive frequent increments of sediment. In contrast, deposits of alluvium are very limited in the gorge of the 
North Fork. Floodwaters are confined by the narrow valley walls, velocities are high, and much of the fluvial sediment is kept in transport; very little sediment is stored in flood-plain or terrace deposits.

Because of the lack of level accessible land throughout much of the Kentucky River area, the low-level terrace deposits are commonly used for housing, agriculture, and business. For example, the business section of Beattyville is built on low-level terraces. These sites are above most frequent floods, but the risk of less frequent (10- to 100-year) floods must be anticipated and accepted.

High-level terrace alluvium $\left(a_{3}\right)$ caps benches above the valley floors and is found in abandoned meander bends and channelways, as at St. Helens. The old, weathered, and leached sediments are generally much better drained than are deposits of clayey or silty alluvium. Large accessible occurrences of these relict deposits should be of great interest to land-use planners because they combine a wide variety of favorable characteristics such as good drainage, stable slopes, and freedom from flooding.

Manmade deposits and modifications.-At the time of mapping (1974-75), extensive spoil (unit s), from strip mining was nonexistent in this quadrangle. Some mine spoil covering a few acres was found between Congleton and the South Fork. The artificial fill (af), engineered for railroad grades and now abandoned, is of possible importance to land-use planning. The abandoned sections of railroad bed running from St. Helens and Maloney flank both sides of the North Fork and continue northward up Walker Creek for many miles through the Zachariah quadrangle. Originally, this railroad line went through a tunnel under the divide to Natural Bridge, Slade, and Stanton in the Red River valley. Although many bridges and trestles have disappeared, the welldrained roadbed of crushed rock survives, although rockfalls or slumps may have locally obstructed it. If cleared it would be a scenic interesting trail for recreational use because of its historical relationship to early logging and commerce of the region.

\section{GAMPTON QUADRANGLE}

The southwestern part of the Campton quadrangle (Newell, $1977 \mathrm{~b}$ ) includes the gorge or canyon of the North Fork of the Kentucky River and entrenched tributaries in smaller canyons. Narrow benches of level to gently sloping land are present above the sandstone rimrock of the canyons. Sinuous ridges and ravines of moderate relief, which occupy the uplands between tributary canyons, rise above the narrow benches. These uplands are com- 
monly underlain by shale and siltstone. The northeastern part of the quadrangle in the area around the town of Campton includes ridge and ravine uplands attaining several hundred feet of relief. These uplands are incised by broad-bottomed low-gradient valleys of the headwaters of Swift Camp Branch and other streams flowing into the Red River. The ridge and ravine uplands are perched on the sandstone bed (Lee Formation) that underlies most of the quadrangle and forms the canyon escarpments. North of Campton, Swift Camp Branch crosses a sandstone scarp and is entrenched below cliffs of sandstone

The bedrock geology of the Campton quadrangle has been mapped and described by Briggs (1957). The lithology and structure of the Lee sandstone has controlled the development of the drainage network and supports the canyon escarpments of the entrenched North Fork and its tributaries. The sandstone of the Lee Formation is generally quartzose and well sorted and contains locally abundant quartz pebbles. This unit is 275-300 feet (84-91 $\mathrm{m})$ thick. It dips gently southward approximately parallel to the gradient of Devil Creek and other south-flowing tributaries of the North Fork. Thus, along most of their reaches, these streams are entrenched in the sandstone.

The Zachariah coal bed at the base of the Breathitt Formation is above the Lee sandstone and has been mined locally, as shown by mine spoil (unit $\mathrm{s}$ ). This coal bed is overlain by basal shale of the Breathitt Formation. The weak shale and coal have been eroded along the edges of the canyon rims and along valley bottoms perched above the Lee sandstone, resulting in broad bottom lands and benches above the rimrock.

Before the North Fork entrenched itself, it cut and abandoned meandering channels through the overlying Breathitt Formation. Remnants of old weathered alluvium $\left(a_{3}\right)$ now repose on benches on top of the Lee sandstone. Some of the old terrace gravels were initially mapped by Briggs (1957). Additional distinctive gravels have also been mapped on the rolling benchland topography above the river gorge. Many other patches of old alluvium have been reworked by erosion and are now too thin and discontinuous to map.

Rounded hills and ridge and ravine topography on the upland areas have formed on shale of the lower part of the Breathitt Formation. Coal beds are discontinuous and are mined at only a few localities. In the northeast corner of the quadrangle, a greater abundance of sandstone beds is revealed topographically by a 
horizon of steeper slopes underlying gently sloping rounded hilltops.

Residuum.-The few extensive mantles of residuum in the Campton quadrangle are found along the benches and old meander bends above the North Fork gorge. Smaller patches on many small benches cap the spurs of bedrock that rise between entrenched south-flowing tributaries of the North Fork. Even smaller patches of residuum, mostly deeply weathered red and yellow clay, cap the sinuous ridge crests and low rounded hills. These patches are, however, too small to map at $1: 24,000$ scale. The residual materials of the more extensive benchlands are supported by the Lee Formation. They consist of deeply weathered shale, clay, coal, and underclay, and friable reddish sandstone and sand. Deeply weathered old alluvium, difficult to distinguish from bedrock residuum, can be identified by the presence of weathered chert and quartz. Chert and quartz pebbles are not found in the local bedrock and have probably been transported from source rocks along Pine Mountain, and perhaps from limited outcrops along the tops of the highest mountains in the North Fork drainage basin.

Colluvium.-Most colluvium is thin and continuous (unit $c_{2}$ ) and is distributed on moderately rolling ridge and ravine topography of the upland interfluves and headwater uplands. Most of the colluvium is derived from shale and consists of silt, clay, and small flat shale pebbles. The material is thick on the bottoms of hollows and thins out on the side slopes and ridges. Landslides, slumps, and mudflows are common where the colluvium is undercut by streams. Many rills and gullies, which have debris fans of eroded material at their mouths, cut the upper slopes. On a very local scale, these features are readily distinguished. They are much too small to show at the map scale, however, being only tens of feet across.

The thin discontinuous colluvium $\left(c_{1}\right)$ underlies steep slopes and canyon walls. It includes steep nearly vertical bedrock escarpments. At the bases of slopes, the colluvium merges with floodplain alluvium. Along the North Fork channel, colluvium is constantly undercut by the river; this process results in periodic slumps and slides from the steep slopes.

A few large debris fans of colluvium and landslide material, which are distinguishable, have been mapped separately as thick colluvium $\left(\mathrm{c}_{3}\right)$.

Alluvium.-Alluvium in the Campton quadrangle is of two types, (1) modern channel and flood-plain alluvium, and (2) old terrace remnants in abandoned channels as much as 300 feet 
$(91 \mathrm{~m})$ above the present entrenched course of the North Fork of the Kentucky River.

Modern channel and flood-plain alluvium $\left(a_{1}\right)$ is formed as much as 40 feet $(12 \mathrm{~m})$ above the river at base flow, coincident with high flood stages of the river in a narrow constricted valley. The alluvium in these deposits is sandy because the river drains an area that has a relatively high percentage of sandstone beds. Alluvium in the North Fork gorge is not continuous; it forms bars along the sides of the channel and on the insides of meander bends. Where the outsides of meander bends are cut into bedrock, alluvium is either absent or is mantled with colluvium. River erosion of the toe of a slope underlain by colluvium maintains mass movement on that slope. Old terrace alluvium $\left(a_{3}\right)$ lies high above the modern channel. The arcuate trend of ancestral channels is easily discernible on the topographic map. The alluvium in the old channels has been intensely dissected and reworked so that remnant patches are generally thin and discontinuous. Locally these patches are as much as 20 feet $(6 \mathrm{~m})$ thick. Old alluvium is primarily recognized by its component rock types, which differ from residuum derived from bedrock. The remnants of old channels that can be discerned above the Lee sandstone were much broader than the present river channel, which is now entrenched within the sandstone. In fact, the ancient channels, their deposits, and bottom lands were probably most similar to currently existing fluvial landforms on topography carved from shale. Examples can be seen along the South Fork at Booneville and along the Middle Fork at St. Helens.

Manmade deposits and modifications.-Surface mine spoil at the time of mapping was limited to a few isolated localities and probably constituted less than 1 percent of the total quadrangle area. Extensive artificial fill is localized along the two main transportation routes through the quadrangle-the Mountain Parkway, and State Highway 15.

\section{HAZARD NORTH QUADRANGLE}

The rugged mountainous terrain of the Hazard North quadrangle (Newell, 1977b) is typical of the headwater counties of the Kentucky River area. Residuum and alluvium, the materials commonly found on uplands and valley bottoms, are very scarce in this quadrangle, and the gentle slopes that they underlie have been intensely utilized since the earliest settlement of man. Most of the steep slopes are underlain by varying thicknesses of colluvium. 
Because of the absence of level land and the relatively high population density, many homes, farms, and some businesses have been constructed on steeply sloping terrain. Intensive use of steep slopes requires careful consideration of the bedrock and surficial details of individual sites and roads.

Residuum.-Extensive areal distributions of residual materials weathered from bedrock are lacking on the ridge and ravine topography of the Hazard North quadrangle. Some narrow wellto excessively drained benches of sandy soil above massive ledgeforming sandstone beds are mappable but cannot be delineated accurately on the 40 -foot $(12 \mathrm{~m})$ contour interval of the topographic base map. Thin unmappable residuum also is found on isolated hilltops and small benches formed on geologically significant marine shale and limestone beds. These beds and some significant ledge-forming sandstone beds have been mapped and described by Seiders (1964) .

Colluvium.-Most of the Hazard North quadrangle consists of steep mountainous slopes mantled with colluvium. The colluvium is thickest and most extensive on the concave-upward slopes of coves and hollows. It forms a wedge-shaped mantle, thickest at the base of the slope. The colluvium thins on side slopes and grades into a very thin discontinuous mantle on adjacent convex-upward slopes. Partially weathered bedrock either crops out or is near the surface on the convex-upward slopes. Residual materials are found on some slopes but are too limited to map separately. Landslides and debris fans are common features at the base of steep slopes and in the mouths of small valleys, ravines, and chutes. Topographic detail is insufficient, however, to map any but the very largest.

Alluvium.-Distribution of alluvium is limited almost exclusively to modern channels. Vestiges of higher older terraces are present at Airport Gardens and in the Hazard area. Alluvium cannot be subdivided because of limited extent and the difficulty of interpretation on a map base that has 40 -foot contours.

Alluvium in tributaries, larger creeks, and the North Fork of the Kentucky River reflects the high sand-shale ratio of the local bedrock. In contrast with the clayey alluvium of the South Fork of the Kentucky River, the alluvium of the North Fork and its tributaries is sandy. Overbank sediment from spring floods is dominantly sand, and the alluvial bottom lands are better drained than regions where bottom-land alluvium is derived from shale. Because of the steep narrow valleys, flood response is rapid, and 
ground-water storage, although better than in clayey alluvium, is minimal.

Manmade deposits and modifications.--The extensive coal resources of the Hazard North quadrangle have been exploited by surface mining of increasing magnitude in recent years. The spoil (unit s), and high walls of the stripping and augering operations have now attained proportions that are readily observable even on the 40-foot contour interval of the base map. Their size and extensive distribution ranks these manmade deposits as significant surficial geologic features having mappable characteristics.

\section{DERIVATIVES FROM SURFICIAL GEOLOGY}

Each type of deposit or residual accumulation defined and mapped in the Beattyville and other quadrangles is continually modified by three geomorphic processes-weathering, mass movement, and streamflow. Map units may be ranked according to the intensity or magnitude and frequency of their respective causative processes (as shown in tables 1 and 2). Thus, the effects of each process over the total map area may be compared. Each process can be identified with corresponding implications for land use. Weathering, associated with permeability, is a factor influencing drainage characteristics. Low-flow and flood-flow characteristics of stream processes are especially important. Mass movement is most active on unstable slopes, which are delineated by mapping landslides and colluvium.

By reinterpreting surficial map units in terms of the effects of each process, derivative maps can be produced showing flood-prone areas, areas of stable or unstable slopes, and areas of good to poor drainage.

\section{FLOOD-PRONE AREAS}

The simplest derivative map that can be produced from the geologic information is a flood-prone-area map. A flood-prone area can be delineated by grouping all areas underlain by modern channel and flood-plain alluvium (unit $a_{1}$ ) and low-level terrace alluvium (unit $\mathrm{a}_{2}$ ) (Newell, 1977b). A comparison of these two surficial units with the flood-prone-area map of the Beattyville quadrangle (Davis, 1977b) generated by hydrologic techniques, shows remarkably good agreement.

\section{SLOPE STABILITY}

Producing a derivative map of slope stability from a surficial geologic map is more complex because it involves the interpretation 
of each map unit for susceptibility to mass movement. By consulting table 1 and combining units of equivalent susceptibility, slope-stability categories can be defined and compiled. The slopestability map of the Beattyville quadrangle (Newell, 1977c) is a simple three-unit example depicting three categories of slope stability: (1) stable (derivative map unit $S$ ), (2) potentially unstable (derivative map unit $\mathrm{P}$ ), and (3) unstable (derivative map unit U). Units designated as "S" are composed of thick residuum, high-level terrace, and (or) low-level terrace. Units designated as "P" are composed of thin continuous colluvium, thick colluvium, and (or) thin residuum. Units designated as "U" are composed of thin discontinuous colluvium and (or) channel alluvium. The stable unit delineates those areas where naturally occurring largescale mass movement is unlikely and where intensive manmade earth-moving operations are likely to create only small-scale mass-movement features, such as limited slumps, mudflows, and gullying. Corrective action in this unit is highly feasible. The potentially unstable category covers a broad diversity of terrain, including areas that formerly may have been active. Various manmade modifications can result in a wide array of massive to limited slope failures, which may or may not be feasibly correctable. The unstable unit delineates those areas on which mass movement is currently being caused by natural geomorphic processes. Corrective action of the resulting mass slope failures is almost always impractical.

Slope maps prepared photomechanically by the U.S. Geological Survey (1974a-c) from topographic base maps of the Beattyville, Campton, and Hazard North quadrangles can be used as an aid to interpreting areas within the diverse category of potentially unstable units. The map units of the slope maps have been selected according to characteristics favorable for various uses: low-angle slopes suited to cultivation, moderate slopes useful for pasturage, steep slopes for woodlands, and very steep slopes that exceed the limit suggested in strip-mine legislation that was considered but not passed in 1973-74.

A comparison of these slope maps and the slope-stability map by Newell (1977c) reveals that all areas delineated as stable on the slope-stability map correspond to areas mapped as low or moderate slopes on the photomechanically prepared maps. Areas delineated as unstable by Newell correspond to areas of steep to very steep slopes. The potentially unstable areas mapped by Newell include all the slope-map units. Thus, small areas mapped as 
potentially unstable should be analyzed on the basis of the corresponding slope-map units and surficial-map units.

\section{DRAINAGE}

A third, more complex derivative map would show the permeability and drainage of the surficial deposits and residual materials. Such a map requires not only analysis of the weathering products developed on each unit but also detailed information about the source rocks from which the surficial materials were derived. Because current detailed bedrock information is lacking, we have not attempted a derivative map of this nature. Although it is not currently feasible to produce an accurate map of drainage characteristics, the concepts involved can be arranged in a framework that will facilitate evaluation of the various data currently available. As new data are produced, more accurate interpretations result; ultimately, a map will be possible. Comparison of this type of map, when produced, with slope-map information should resemble data found in the Lee County soil survey (U.S. Soil Conservation Service, 1974). All the geologic factors that affect permeability and drainage also affect soil-forming processes.

Good or poor drainage of surficial deposits and weathered horizons depends on several variables, the most important ones being the porosity of the surficial material, its thickness, and the angle of the slope it underlies.

Porosity of surficial material is dependent largely on the source rocks from which the material was derived. Surficial materials derived from sandstone are better drained than those produced from shale and siltstone. Weathering can increase the porosity and consequently improve drainage of some materials. Assuming that, for the most part, the pore space of the rocks and that of surficial materials is interconnected, porous materials will be highly permeable. If permeable materials are sufficiently thick, the slopes they underlie will be well drained. Moreover, areas underlain by thick accumulations of permeable materials may be favorable for storage of ground water. Figure 8 shows the general relationship between porosity and thickness of surficial materials.

By comparing equivalent thicknesses of various surficial materials, the effects and interactions of slope and rock type on drainage characteristics can be evaluated. The steepness of the hill slope affects the rate at which surface water runs off and ground water is discharged. Rock type influences permeability of surficial materials; permeability in turn affects the relative 


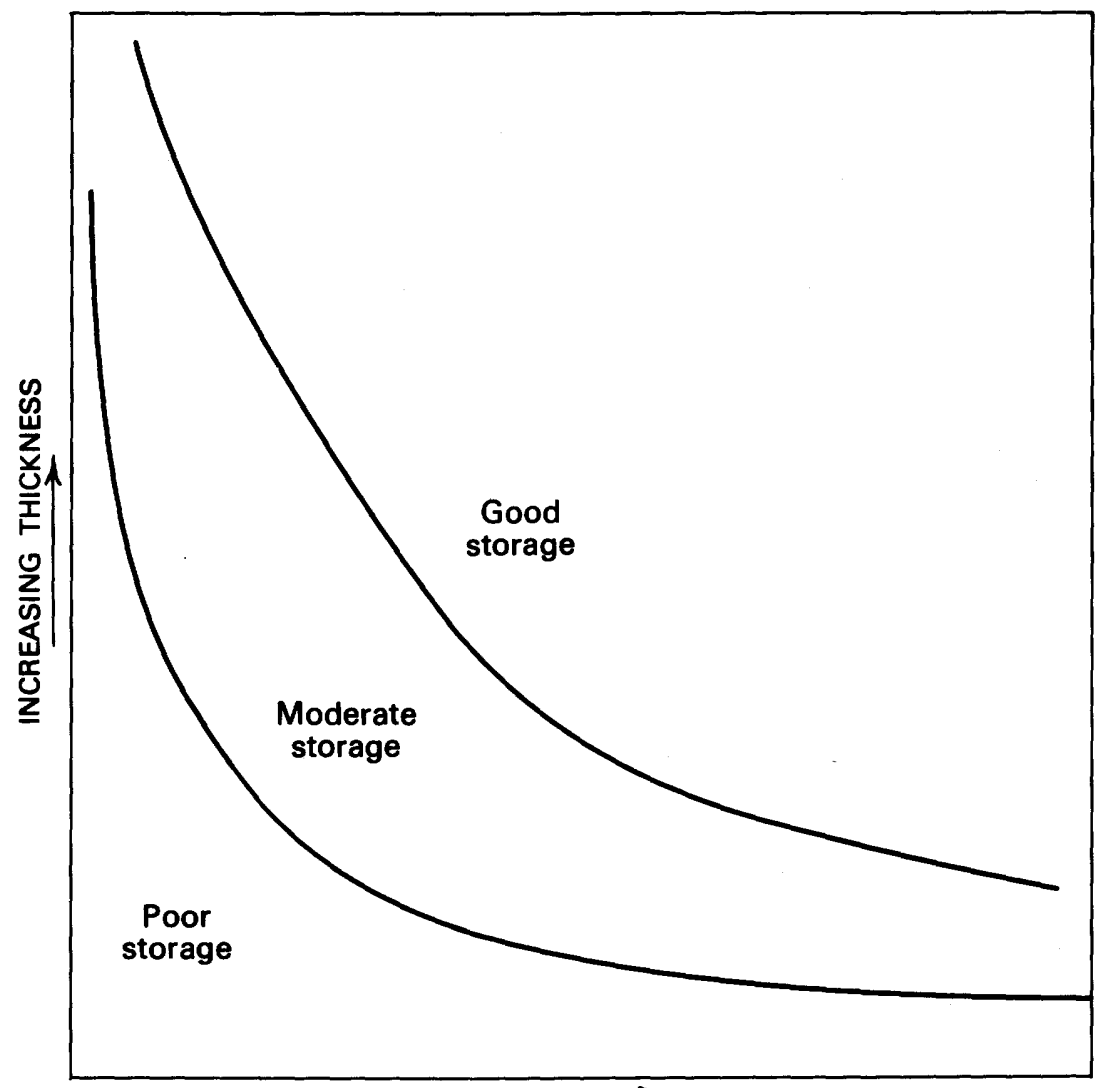

INCREASING POROSITY (FUNCTION OF BEDROCK)

FIGURE 8.-Graph showing relationship between porosity and thickness of surficial materials and the effects of these variables on ground-water storage.

amounts of water retained and stored within a deposit and the amount that runs off the surface during storms. Figure 9 shows the distribution of drainage and storage characteristics of surficial materials derived from permeable and impermeable rock types, depending on the angle of the slope on which the materials lie.

Figures $9 B, C$, and $D$ show the distributions of slopes and rock types that characterize the various naturally occurring units shown on the regional surficial map (Newell, 1977a). Some units having different origins have similar characteristics, whereas some units are highly variable because of a wide range of rock type and slope effects.

Although figure 9 is shown without numerical values for perme- 
ability and slopes, these factors can be defined by measuring permeabilities of different surficial materials and determining corresponding slopes from the $71 / 2$-minute quadrangle slope maps (U.S. Geol. Survey, 1974a-c). If a complete derivative map of the drainage characteristics of the quadrangle is required, map units can be defined by using the characteristics of each of the four quadrangles of figure 9 .

Because a surficial map unit on different rock types has different drainage characteristics, it may be divided into several derivative map units. The construction of a derivative drainage map, unlike that of a derivative slope-stability map, requires not merely the addition of various appropriate surficial map units but rather the division of these units and the recombination of parts having similar drainage characteristics.

As shown on figures $9 B, C$, and $D$, the best drainage characteristics are provided by thick residuum, low- and high-level terrace alluvium, and by some deposits of thick colluvium. Clearly, the thickest surficial materials (fig. 8) with favorable drainage or storage characteristics will be the most adaptable for a variety of land uses.

Hopefully, these suggestions for derivative maps will stimulate a comprehensive understanding of geomorphic processes operating together as a system upon the terrain and underlying bedrock to produce the variety of surficial deposits and residual accumulations. Some processes and associated deposits present opportunities for safe and beneficial use. Others may constitute obvious hazards, which, depending on intensity and magnitude, should either be avoided or overcome by engineering modifications. Within these perspectives, the variety of geologic materials can be used in several ways.

First, geologic information can be used to select sites having high potential for a variety of safe and beneficial uses. The St. Helens abandoned-meander-bend area is a good example of such a site. Not a flood-prone area, it combines good drainage characteristics with stable slopes and is readily accessible. Other areas, such as flat uplands that are not flood prone and that include well-drained stable slopes, are generally somewhat less accessible. For some uses, however, upland areas may have a more favorable microclimate and flow of air than the more enclosed surroundings of abandoned meander bends. The regional surficial geologic map (Newell, 1977a) indicates that both types of favorable localities, broad upland benches and abandoned meander 


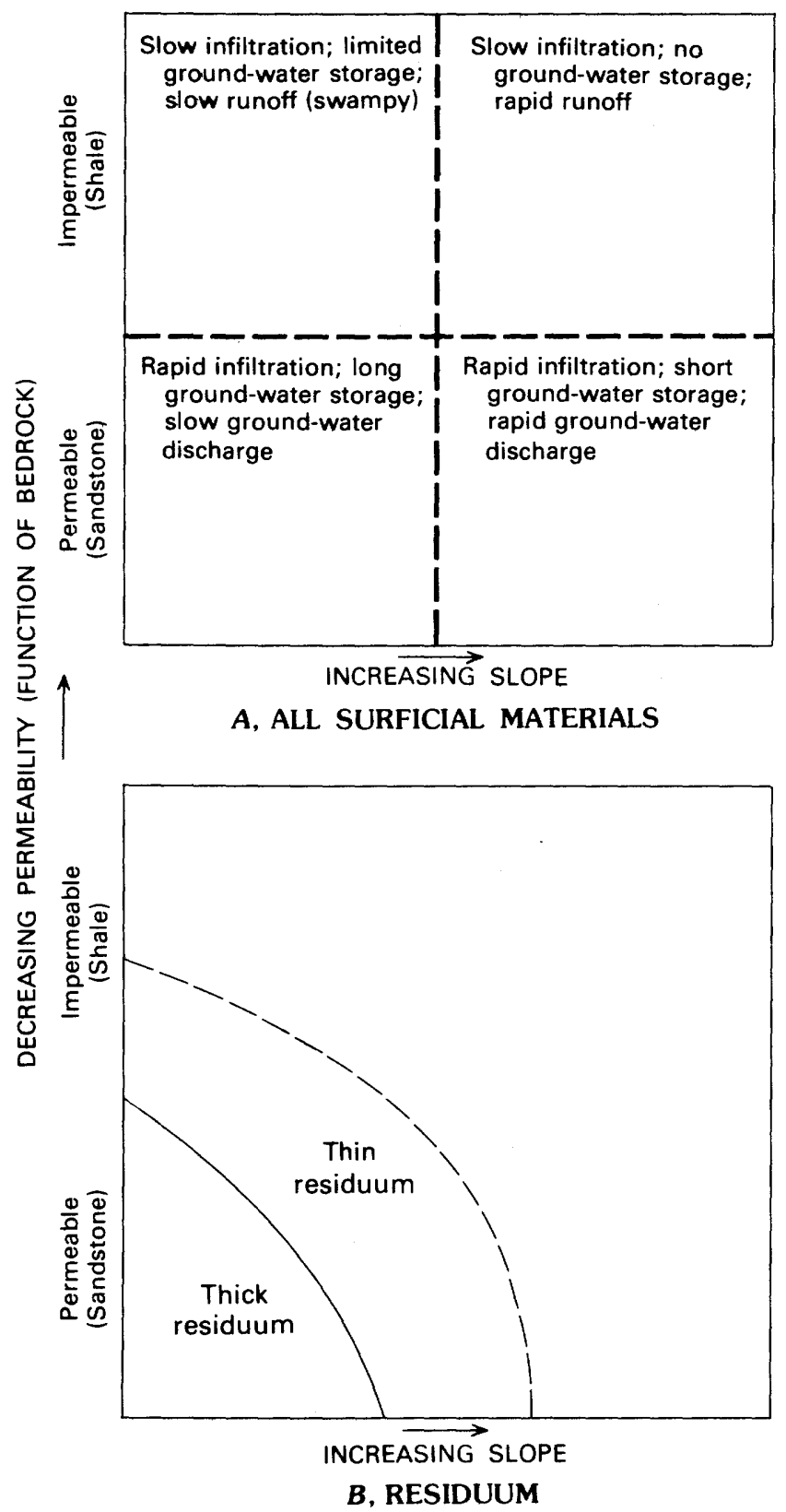

Figure 9.-Graphs showing relationship between permeability and slope for different surficial materials and the effects of these variables on ground water. $A$, All surficial materials; $B$, residuum; $C$, colluvium; and $D$, alluvium. 


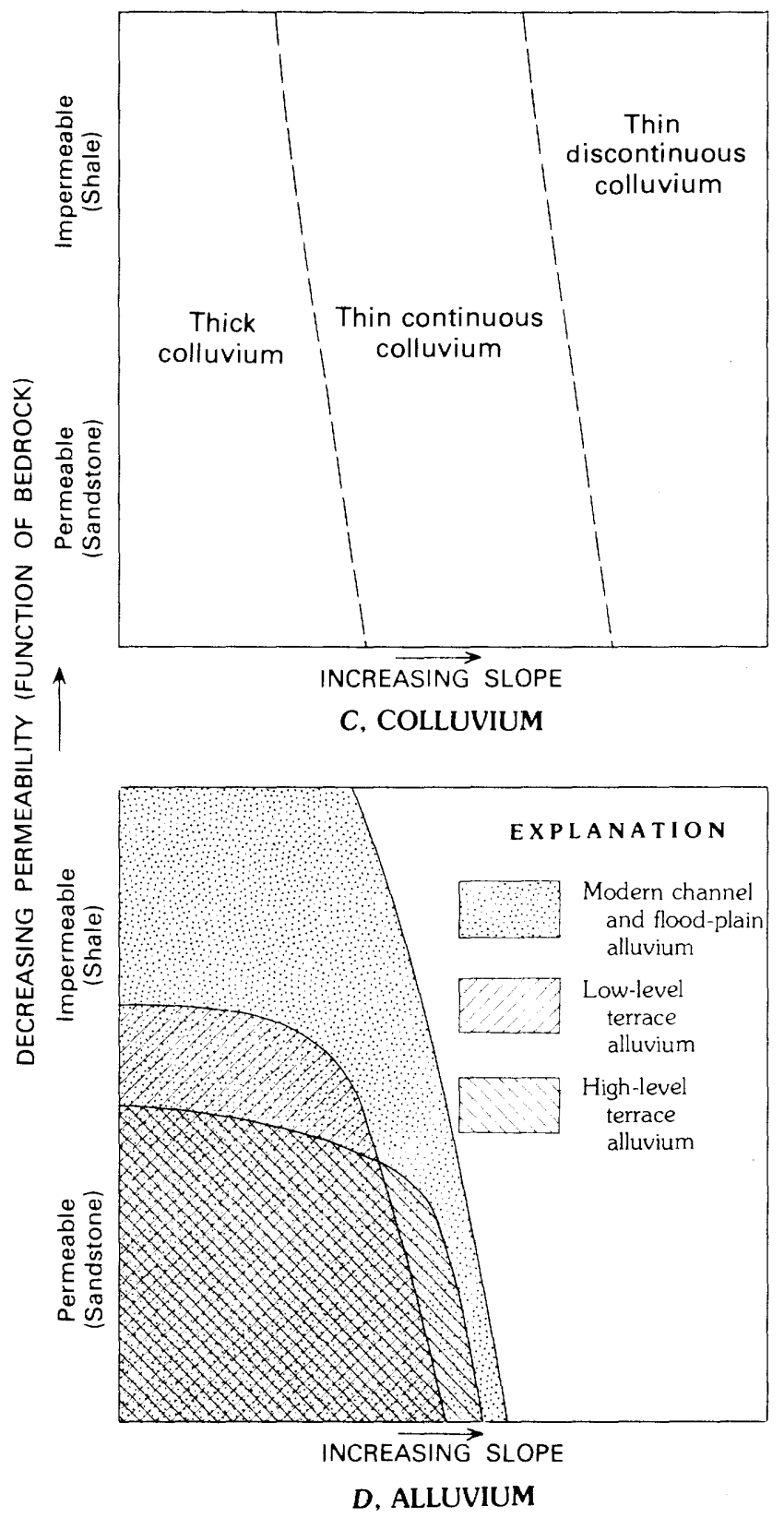

Figure 9.-Continued. 
bends, are uncommon and should be wisely utilized, using careful planning for maximum returns.

Because highly favorable and adaptable sites are rare in the Kentucky River area, a second, perhaps more pragmatic, application of geologic information is in the evaluation of areas and corridors already selected for use in accord with political and economic constraints. Under these circumstances, geologic information can be helpful in anticipating design and construction problems that might arise at sites that are potentially unstable, poorly drained, or flood prone. When used for these purposes, the map data at the scale provided should not be construed to imply specific site information. Consideration of specific sites requires larger scale detailed analysis than is possible at the scale of the regional maps.

\section{RESOURCES}

\section{MINERAL-FUELS MAPS}

GOAL

A map of coal resources (Newell and Rice, 1977b) has been prepared to show areas of abundant coal. At the map scale of $1: 125,000$, the quality and distribution of all significant individual coalbeds cannot be shown. Information regarding the distribution and occurrence of coal on a more detailed scale $(1: 24,000)$ can be obtained from U.S. Geological Survey quadrangle maps.

Some coal statistics can be mapped and studied at the regional map scale to indicate the relative abundance of coal. These include total aggregate thickness of all coal beds, total number of coal beds, average thickness of coal beds, and the single thickest coal bed. These factors can be used with additional geologic data to interpret the regional depositional history of the rocks. However, for the purposes of regional planning it is merely necessary to indicate areas where coal is either abundant or not abundant as a resource. This information is useful for the identification of areas where coal extraction may be in potential conflict with other land use. Planners should be aware not only of potential conflict but also of the engineering and reclamation problems that might be contingent upon using land after mining has been completed.

Two summary values have been chosen to show the regional distribution of coal in rocks above drainage in the Kentucky River area: (1) The total number of coal beds more than 1 foot $(0.3 \mathrm{~m})$ thick and $(2)$ the total thickness of coal beds more than 
1 foot $(0.3 \mathrm{~m})$ thick. A 1 -foot $(0.3-\mathrm{m})$ thickness was chosen as the lower limit to eliminate the many beds less than 6 inches $(15 \mathrm{~cm})$ thick that will probably never be of value. These data were compiled and contoured from the same basic information sources used to construct the Kentucky River area bedrock map (Newell and Rice, 1977a). The map of coal abundance correlates well with the bedrock map, essentially reflecting the original basin conditions during the time of sediment and coal accumulation. In the northwestern counties, thickness of coal is generally unimpressive, the aggregate of.a few thin beds. This area of thin beds is also an area of low topographic relief underlain by shale. More rugged topography exposing greater percentages of sandstone contains more abundant, thicker coalbeds that have a proportionately greater aggregate thickness of coal.

Figures $10 A, B$, and $C$ show relationships among the thickness of coal beds, the number of coal beds, and the thickness of exposed stratigraphic sections. The graphs show trends that are consistent with the regional geology. Although data in figures $10 A$ and $B$ are scattered considerably, the total number of coal beds and the total thickness of coal beds are related to the thickness of stratigraphic section exposed. These relationships actualīy reflect the original environment of deposition within the coalbearing basin. Abundant shale and a few thin coal beds occur on the basin margin, whereas thick sandy sequences containing abundant thick coal beds are found near the center of the basin. Sandy sequences are able to support high-relief topography; shale sequences, on the other hand, weather to gently rolling topography.

Figure $10 \mathrm{C}$ illustrates a striking relationship between total thickness of coal beds and number of coal beds greater than 1 foot $(0.3 \mathrm{~m})$ thick. The aggregate thickness increases by approximately a factor of two times the total number of coal beds. Thus, areas having a greater abundance of coal beds can be expected to have a proportionately greater aggregate thickness of coal beds. Both types of data indicate that coal is least abundant through the northwestern counties-Wolfe, Lee, and Owsley. It is most common in the central mountainous counties.

The distribution illustrated by the coal-accessibility map (Newell and Rice, 1977b) is substantiated by comparison with the distribution of strip-mined land shown on the land-use map (U.S. Geol. Survey, 1975). The most extensive distribution of stripmined areas is within areas containing more than 10 coal beds having an aggregate thickness greater than 20 feet $(6 \mathrm{~m})$. Although there is an anomaly east of Hazard, mining was extensive 

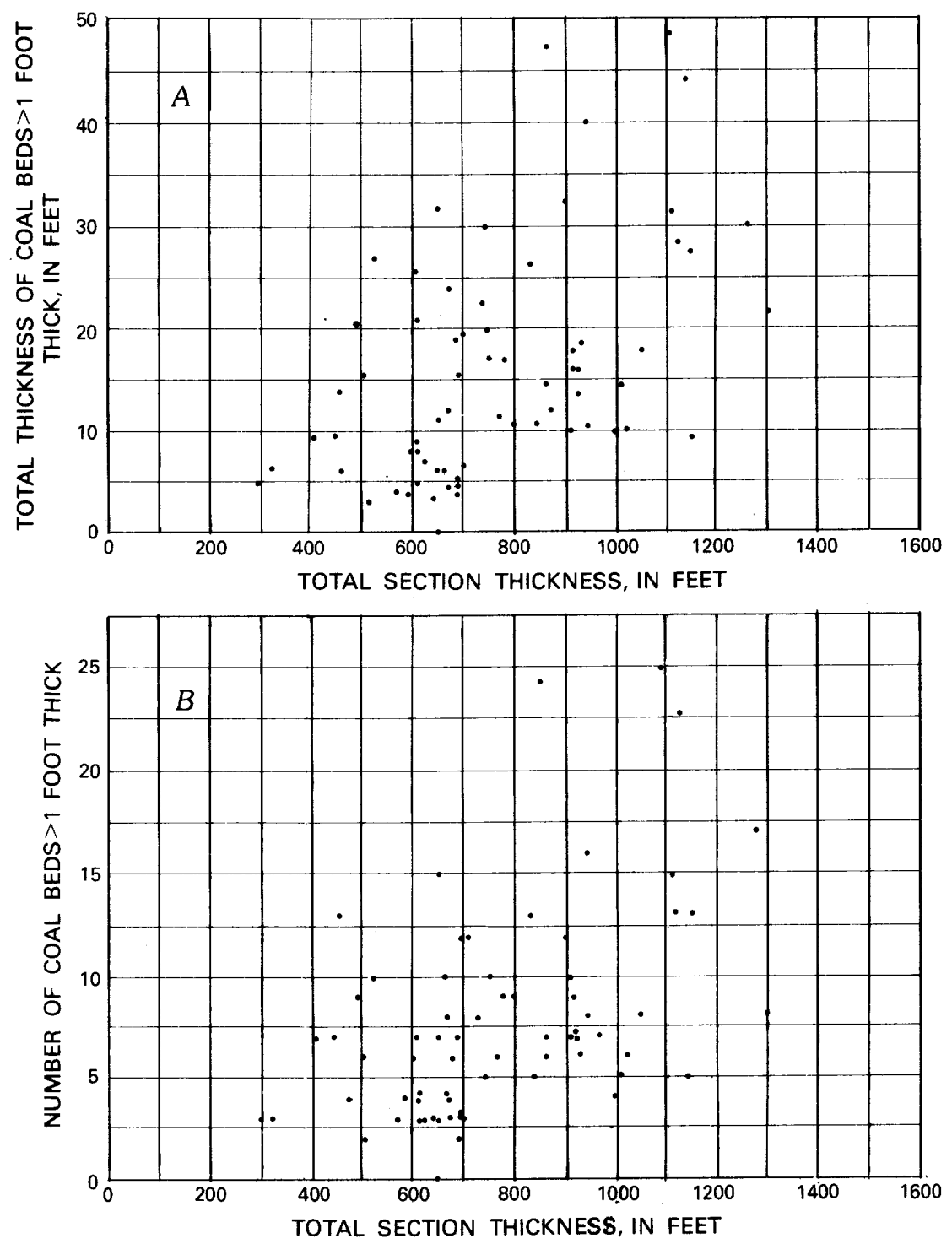

Figure 10.-Graphs showing relationships among thickness of coal beds, number of coal beds, and thickness of exposed stratigraphic sections.

there, indicating that a few readily accessible thick beds have been widely exploited. This situation could probably be shown better by mapping the distribution and thickness of the thickest single coal bed. 


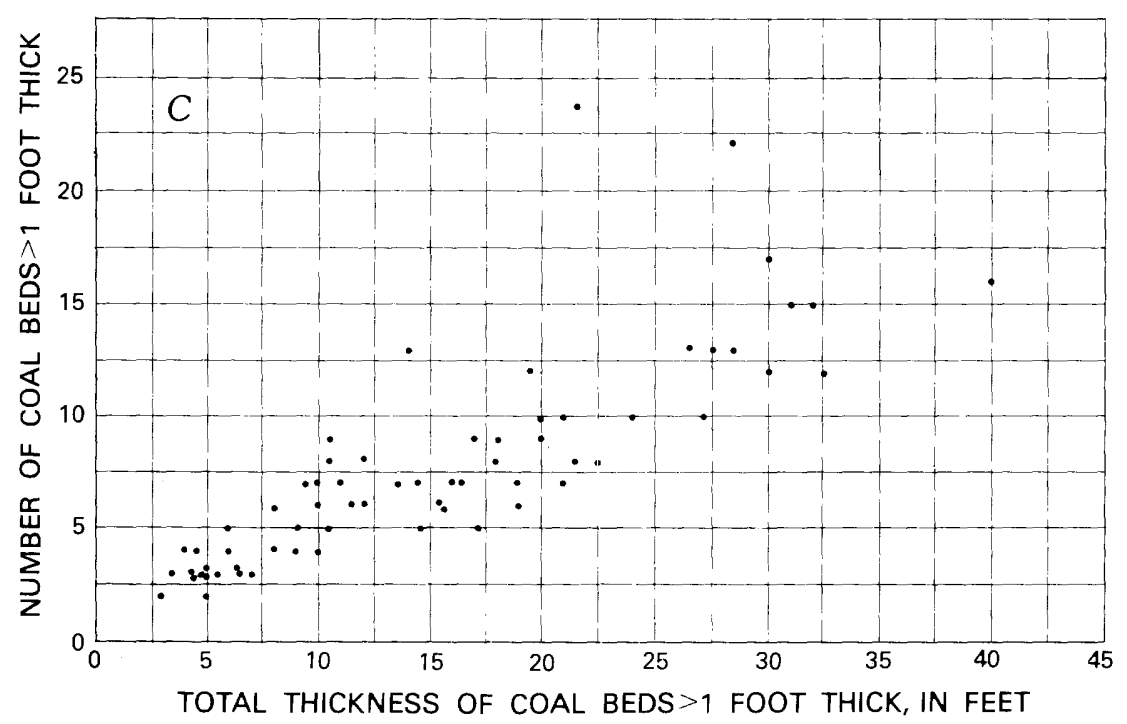

FigURE 10.-Continued.

OIL AND GAS

Other mineral fuels found within the Kentucky River area include oil and gas. The land-use map (U.S. Geol. Survey, 1975) shows an extensive oil and gas field in the Big Sinking Creek area of Lee County. Other smaller fields and individual wells are found throughout the region. The Kentucky River area is included in the recent comprehensive compilation of oil and gas resources in eastern Kentucky by the Kentucky Geological Survey (Wilson and Sutten, 1976).

\section{WATER-RESOURCES MAPS}

Several kinds of hydrologic data that can benefit land-use planning have been collected, analyzed, and compiled on $1: 250,000-$ and $1: 24,000$-scale maps of the Kentucky River area. These data indicate the availability and quality of water from ground-water and surface-runoff systems. Such information is essential to a complete understanding of the region's resource base. The abundance or lack of ground-water aquifers and the concentration of chemical constituents are dependent on the porosity and mineralogy of the bedrock. Information on ground-water abundance and quality is presented on two regional-scale maps. One map (Davis, 
1977a) shows yields from selected deep wells-and the availability of potable water from aquifers in sandstone beds at the base of the Pennsylvanian. A second ground-water map (Davis, 1977d) shows chemical characteristics of selected wells.

Various streamflow characteristics reflect the slopes and the surficial materials found within contributing watersheds. A map (Davis, 1977b) of average discharge from the Kentucky River, its three forks, and their tributaries, illustrates the relationship between discharge and drainage basin area and the cumulative increase of discharge downstream. Two streamflow characteristics, flood-prone areas and 10-year, 7-day low-flow values, have special environmental significance. Low-flow data from selected gauging stations has been plotted on the surface-water-availability map (Davis, 1977b). This map also includes a small index map showing availability of $71 / 2$-minute topographic quadrangle maps on which flood-prone areas have been defined.

\section{EFFECTS OF GEOLOGY AND LAND USE ON WATER QUALITY AND AVAILABILITY}

Quality of surface water in any one place is not constant because it is affected by changing land and water uses. The effects of intensive land use on water quality are documented on two maps by Davis $(1977 \mathrm{c}, \mathrm{e})$. One shows the total concentration of dissolved solids and their chemistry. The other supplementary map shows the concentration of sulfate ion, which is a direct indicator of the effects of coal mining on water quality. Both maps also show the effects of dilution of high concentrations of dissolved materials by mixing downstream with water of lower concentration discharged from drainage basins largely unaffected by mining or other intensive use.

Although the primary function of these maps is to catalog and define water resources, they are also useful in qualitatively portraying the relationship of water resources to geologic and topographic features and the current patern of land use. However, this interpretive value is limited, because of its regional scale, to some fundamental generaliżations. No doubt, detailed studies of individual watersheds would provide interesting and useful geologic interpretations and predictive information on available water resources. Such studies are beyond the scope of a regional assessment of the Kentucky River area water budget.

Occurrence of brines at depth in sandstone aquifers at the base of the Pennsylvanian has been generally predicted on the map. However, other correlations between bedrock and ground-water 
yield and quality, at the regional scale and using the available data, are currently nonexistent. The lack of predictable patterns reflects the locally discontinuous occurrence of bedrock-aquifer materials (porous sandstone) within the heterogeneous Breathitt Formation. A regional assessment does show that the overwhelming abundance of steep mountain slopes covered with colluvium of variable thickness and permeability provides poor storage resulting in low base flows from extensive watersheds. Ephemeral or low base flow from much of the region may inhibit or severely limit some types of land use or industrial development unless minimum water requirements can be met by surface-water impoundments or augmentations from deep wells.

Both the total-dissolved-solids map (Davis, 1977c) and map of sulfate-ion concentrations (Davis, 1977e) reflect land use and bedrock geology in the South, Middle, and North Fork basins. The North Fork basin has the highest concentrations of sulfate ion, because it is the area of most intensive mining (a result of coal abundance and recoverability). The Middle Fork has the lowest concentrations because of the relative lack of mining and the preponderance of forested slopes. The South Fork basin, although limited in mining, includes the largest expanses of open agricultural land. Water from this basin is slightly higher in dissolved solids than that of the Middle Fork because of the limited mining, the exposure of soil and weathered rock resulting from agricultural activities, and possibly the application of fertilizers. As further documented by the maps, the confluence and mixing of Middle Fork and South Fork water with North Fork water significantly dilutes, possibly by as much as an order of magnitude, the higher concentrations of sulfate ions from the North Fork.

The ephemeral quality of surface water and the existing pattern of dissolved-solid concentrations may be of interest and use in illustrating various philosophies with regard to water use.

One alternative commonly considered is to upgrade the quality of all surface water to the purest possible state, possibly purer than the natural system is capable of producing. The desire to carry out such a plan results from the assumption that all water everywhere ought to be clean. In many drainage systems, however, it is not geologically, hydrologically, or economically feasible to put this idealistic philosophy into practice.

A contrasting philosophy stipulates that everyone has the right to as much dirty water as he wants; clean water is a buyable quality, which is engineered for those who require it, and which can be had wherever needed if the user can afford it. Although 
this system may seem to be the inevitable outcome of common rights to water, it actually precludes some possibilities for water, land, and resource use.

A third possibility, the planned coexistence of clean and impure river systems, suggests that some rivers and their watersheds are ideally suited to provide abundant clean water, low in dissolved constituents and sediment. In other parts of a drainage system, however, because of mineral resources, mining, and (or) industrial uses, it is physically and economically difficult to maintain water of high quality or to restore water to high quality. By planning, clean and impure water systems can be established as coexisting tributaries in a regional drainage basin of acceptable quality. The clean water of one stream can be mixed with the polluted water of the other, thus producing downstream water of a uniform predictable quality, which should ultimately be of higher quality than water produced from a system in which all tributaries are polluted.

The prevailing system of water and land use in the Kentucky River area illustrates the feasibility of this last alternative. Because of the geology and resulting exploitation, this ephemeral system could be maintained, possibly gradually improved and exploited, to provide water of differing qualities, suitable for various uses. Most of the mining and industry in the North Fork area will probably continue. If deemed desirable, the other two forks could be maintained as sources of purer water, which could be used to dilute North Fork water.

\section{LAND-USE PATTERNS}

\section{LAND-USE MAP}

A map of current land use in the Kentucky River area has been prepared at the regional scale of $1: 125,000$ (U.S. Geol. Survey, 1975). Four major land categories-urban and built up, agricultural, forest, and barren-have been subdivided and mapped according to specific uses. The first major category includes various types and combinations of residential, business, and industrial uses. Agricultural land is subdivided according to uses, such as cropland and pasture, orchards, or feedlots. Forest land is subdivided according to dominance of deciduous or coniferous trees. Barren land includes areas that have been strip mined or quarried.

\section{RELATIONSHIP OF MAP TO GEOLOGY AND RESOURCES}

The regional distribution of the four land categories shows a current pattern of use that is a result of changing economic condi- 
tions interacting with the opportunities and limitations of the natural resource base. Comparison of the land-use map with the geologic and hydrologic maps reveals obvious correlations between various uses, occurrence of resources, potential residential and industrial sites, and transportation networks.

Urban and built-up land on the valley sides and bottom lands of major drainages is most commonly underlain by alluvium or colluvium. Although these locations are convenient to current and previously existing transportation and waterpower, they are also susceptible to flooding and to problems of slope stability. Some urban or industrial localities built on bench tops of high terraces underlain by residuum or weathered alluvium are less vulnerable.

Agricultural land in the Kentucky River area is mostly limited to cropland and pasture. Probably as much as $85-90$ percent of all land mapped as agricultural on the land-use map is in Lee, Wolfe, and Owsley Counties. Approximately half the agricultural land in these three counties is on alluvium in broad valley bottoms. The balance of cropland and pasture is mostly on residuum underlying nearly level uplands. Mappable agricultural land in the remaining Kentucky River area is practically nonexistent. It is confined to narrow bottom lands and some steep hill slopes. Ridge crests underlain by residuum are too limited and isolated to be widely used. Locally, some mountaintops are cleared for pastures and fields.

Of the forest types, extensive stands of coniferous and mixed coniferous-deciduous forest are mapped only in Wolfe and Lee Counties and part of Owsley County. This distribution reflects the widespread occurrence of sandy well-drained soil developed from outcrops of sandstone at the base of the Pennsylvanian. Elsewhere, deciduous forest prevails. Limited sandstone outcrops of the Breathitt Formation along ridge crests and steep slopes commonly support conifers, but these outcrops are too small to map. On a local scale, variations in the distribution of forest species reflect not only differences in soils and drainage but also prevous episodes of clearing and revegetation whether by fire, timber cutting, cultivation, or mining.

Strip mines and quarries are most common in the rugged mountainous terrain of the central and eastern counties of the Kentucky River area. Strip mines are much less common in Lee, Wolfe, and Owsley Counties where agricultural land is more abundant. Comparison of the land-use map (U.S. Geol. Survey, 1975) with the coal and bedrock maps (Newell and Rice, 1977a, b) indicates that areas having the greatest concentration of coal 
mines coincide with areas containing the greatest abundance of coal. This is the logical conclusion of an evolving pattern of coal exploration, mining, and the transportation system. Much of the strip-mined terrain coincides with mapped occurrences of extensive colluvium. Thus, the potential for stability problems on the steep mountainous slopes is high. Quarries for aggregate are found along outcrop belts of Mississippian limestone on Pine Mountain and the Cumberland Escarpment on the northwest border of the area.

\section{HISTORICAL PERSPECTIVE}

The limitations and opportunities affecting future patterns of land use are determined by conditions inherited from present and past uses. The distribution and abundance of renewable resources -forests, high-quality water, and, to a lesser extent, land under cultivation-are not static. Throughout the history of the region, these commodities have been exploited from time to time and from place to place and yet rarely have they been permanently destroyed through such practice. Although abundant early reserves of thick coalbeds or shallow oil have been exhausted, the resource base has been increased by technological changes that transform uneconomical deposits into reserves. The indiscriminate extraction of these nonrenewable resources can within a practical foreseeable period limit the land's capability of providing the natural diversity of renewable resources.

\section{SUMMARY AND CONCLUSIONS}

Comprehensive geologic, water, and land-resources information from the Kentucky River area has been presented and discussed from the perspectives of current and potential use. Comparative analyses of this information show that bedrock and surficial geology, quantity and quality of water, and current patterns of resource use are intricately related through a dynamic geomorphic system in which rocks, slopes, and landforms are modified by weathering, mass-movement, and streamflow processes. Hopefully, an understanding of this system will help map users and planners to perceive surficial materials not only as products of geomorphic processes but also as indicators of local process intensity. A definition of the intensity of the landscaping processes establishes guidelines that specify the limitations and opportunities of the natural system for present and future use. Through the 
process-oriented perspective, the effects of manmade stresses on the natural system can be anticipated, avoided, ameliorated, or perhaps even used to advantage.

Obviously, instant answers to all possible questions cannot be expected from the array of regional-scale maps. The regionalscale information has been presented to document geologic and hydrologic trends, define relationships, and establish the concept of a natural system of geomorphic processes. Detailed larger scale examples are intended as guides to the interpretation of the natural system and typical terrain throughout the Kentucky River area. By using the conceptual guidelines of the large-scale maps, additional detailed information can be collected and interpreted for specific sites that are favorable for use.

Let us attempt a review and assessment of the Kentucky River area's potential for land-use planning, especially for sequential multiple use. This assessment is constrained by the lack of corresponding information on economics and human resources. Thus, all examples must be considered hypothetical and possibly idealistic.

Is the Kentucky River area adaptable to planning exercises? If so, at what levels or scales can designs be successfully implemented? Obviously, some areas do present greater opportunities and fewer hazards for use than other areas. Ideally, on a regional basis, it would seem advantageous to encourage certain uses in some areas, different uses in others, and drastically to restrict habitation in or use of still others. However, in a region that already has transportation, settlements, and a long history of habitation and exploitation of minerals, timber, and waterpower, it is unrealistic to take it all apart and make it over again.

Within counties, as opposed to larger regional areas, there may be more possibilities to encourage some use patterns and to abandon others. No doubt; many small-scale projects can be adapted to local conditions where needed. However, there will always be some areas that are better suited for a particular type of use than the areas dictated by economics and politics.

Historically, the region has endured waves of exploitation of natural resources: a period of rapid and thorough timber cutting; a period of improvident agriculture when steep hill slopes were cleared, planted, exhausted, and abandoned to erosion and regrowth of forests; and periods of oil and gas exploration and production. Currently, surface mining for coal modifies the landscape at a scale greater than has been experienced previously.

The lure of profit derived from such exploitation commonly 
eclipses the consideration of other land uses. However, through competition at some localities, agriculture, forestry, or housing are found on the terrain most suitable for those uses. Where urban areas have been established, their growth competes with existing rural land uses. Under present concepts, once an area has been urbanized, other uses are precluded within the foreseeable future. Within the system of competition for mining, agriculture, forestry, and urban growth lies the potential for planning sequential multiple land use based on geologic information.

From the geologic maps referred to in this report, we can see that areas having the greatest diversity of natural resourcesbroad bottom lands, large well-drained level uplands, forested slopes, adequate water, oil and gas, coal, and aggregate for building-are capable of sustaining the greatest diversity of uses. On the other hand, areas having more uniform geology and physiography-endless miles of steep slopes, narrow bottomlands, and limited inaccessible uplands-are dependent on a single-purpose, exploitive economy based on extensive coal reserves.

The land-use map (U.S. Geol. Survey, 1975) indicates that, in fact, Wolfe, Lee, and Owsley Counties have a more diverse array of land uses than do the other five counties. The more diverse the terrain, the greater the possibility for planning sequential multiple use of the land. If the environmental drawbacks of surface mining are ameliorated, surface mining has the potential ability to increase terrain diversity and thus increase the potential for sequential multiple use, an especially critical need in mountainous urban areas where suitable land has already been utilized and risks are incurred on flood plains and steep slopes.

In areas of great natural diversity, a surface mine planned and executed to anticipate future land use can prevent the loss of good agricultural land to housing, business, or industrial expansion. An excellent example of this possibility can be found in the area surrounding Booneville, the county seat of Owsley County. Booneville is surrounded by broad bottom lands and upland benches now used for agriculture and sparse residential areas. Normal expansion of the town would result in less land for agriculture, and the pastoral surroundings would be replaced by industrial, business, and housing developments. There is, however, an alternative. Nearby, to the southwest, several hilltops have been strip mined. These hilltops could be graded and landscaped to satisfy safety and environmental needs and utilized for light industry and residential areas. The pastoral scenery of the Booneville area 
would thereby be preserved, and the diversity of land use and the potential for multiple use would be enhanced. Moreover, areas prone to floods and slope-stability problems could largely be avoided by housing and industry and left to low-risk uses such as agriculture and forestry. Thus, land-use planning can selectively accelerate strip mining or encourage an extension of mining to achieve desirable urban sites.

As a hypothetical case, the Booneville area may offer an ideal situation with good potential for planning sequential multiple use of diverse terrain. However, in reality, economies may be unfavorable for attracting growth because of transportation limitations.

Many urbanized localities in the Kentucky River area have been developed primarily because of coal reserves. In areas such as Hazard, Hyden, Jenkins, and Whitesburg, the need for planning the sequential multiple use of mined land is actually more acute than in the areas of Beattyville, Booneville, Campton, and Jackson. The re-use of mined land may be the only opportunity to avoid problems that can result from the occupation of flood-prone areas or of unstable slopes in the mountainous communities.

For more than 200 years, Appalachian Kentucky has been the scene of exploitive practices. The benefits derived from its timber, coal, oil, and gas resources have been largely realized elsewhere. If the current return to Appalachia of people from industrial urban areas is accompanied by a desire for a dependable economy within the surroundings of a quality environment, then singlepurpose exploitation may be replaced by multipurpose land use, which requires innovative informed planning. If, on the other hand, the single-use exploitive practices prevail, the role of land-use planning will be severely limited.

\section{GLOSSARY OF TERMS AS USED IN THIS REPORT}

Abandoned meander bend.--River bend that has been abandoned by its stream. Alluvium.-General term for unconsolidated sand, gravel, and clay deposited by streams.

Ancestral channel.-A major ancient river channel, older than the present channel.

Angle of repose.-The angle at which a slope can stand without failure (sliding or slumping). This angle depends on the materials present, moisture content, and load (such as buildings) borne by the slope.

Aquifer.-A body of saturated rock or unconsolidated material that is sufficiently permeable to yield significant quantities of water to wells and springs.

Areal distribution.-Pattern of occurrence shown on a map.

Back slope.-The slope above and back of a scarp. 
Basal.-Bottommost in a stratigraphic sequence of rocks.

Bed.-Layer of rocks of a relatively homogeneous internal composition that can be separated from the rocks above and below by some visual or physical characteristic.

Bed load.-The part of the total stream load of sediment that is moved along the streambed. Usually consists of large gravel, pebbles, cobbles, and boulders.

Bedrock.-General term for the rock that underlies soil or other unconsolidated superficial material.

Bedrock buttress.--Rock mass protruding from a mountain or hill and resembling the buttress of a building.

Bedrock control.-Control on topography or drainage exerted by the underlying bedrock. An example of this control is ridge and valley topography where resistant bedrock areas remain as ridges and highs, whereas bedrock less resistant to erosion is worn away to form valleys and low areas. Streams and rivers will be found in these lower areas. In regions of more extensive resistant materials, drainage will follow fractures and breaks (weak zones), and hence is also controlled by the bedrock.

Breathitt Formation.-A complex sequence of sandstone, shale, siltstone, limestone, and coal of Pennsylvanian age, first described in Breathitt County. It underlies most of eastern Kentucky and supplies most of the coal mined from this region.

Caps.-Rests on top of a hill or bench.

Chute.-Steep narrow channel through which water flows rapidly.

Coalescence (confluence).-The intersection of two or more streams.

Colluvium.-General term for loose mixed mass of soil material or rock fragments deposited at the base of a slope by mass movement.

Contour.-(1) An imaginary line on a land surface, all points of which are the same altitude. (2) An imaginary line or surface along which a certain quantity, otherwise variable, has the same value.

Convex-upward slope.-A slope that is domed or convex at the surface as opposed to a concave-upward or "dished" surface.

Debris fan.-Fan-shaped accumulation of debris deposited at the mouth of a gully, ravine, or other channel.

Delineate.-To distinguish and outline mappable features.

Derivative map.-Map showing interpretations derived from basic geologic information.

Drainage basin.-Watershed, catchment. A region or area that gathers precipitation and contributes it to a stream channel or system of channels, lakes, reservoirs, or other bodies of water.

Entrenched meander.-Meander carved downward below the surface of the valley in which the meander originally formed.

Environmental geology.-The application of geologic data and principles to the use of the human physical environment.

Ephemeral stream.-A stream or reach of a stream that flows only in direct response to precipitation and whose channel is always above the water table.

Equilibrium.-Balance between form and processes. For example, the balance between the resistance of rocks along a coast and the erosional force of waves.

Escarpment.-Long, more or less continuous cliff or relatively steep slope facing one general direction that separates two gently sloping surfaces. 
It may be produced by faulting or by differential erosion marking the outcrop of a resistant layer in a series of gently dipping softer strata.

Extractive.-Refers to removal or extraction of minerals, fuels, or aggregate from the earth by various mining processes.

Fault.-Surface or zone of rock fracture along which there has been displacement.

Fining upward.- Refers to sorting of particles in flood-plain deposits that are commonly coarse at the base and fine at the top.

Fluvial.-Pertaining to a river or rivers with regard to river flow, erosion, and deposition.

Formation.-Mappable unit of rock of considerable thickness (from a few meters to several thousand meters) and extent and characterized by some degree of internal physical or chemical homogeneity, such as texture, structure, fossils, or chemical composition.

Friable.-Easily crumbled, broken, pulverized, or reduced to powder.

Geomorphic processes.-Processes affecting the origin of landforms.

Geomorphology.-Study of nature, origin, description, and classification of landforms and their relationship to underlying structures and geologic changes.

Headwaters. - The source (or sources) and upper part of a stream or river, including the upper drainage basin.

Hydrologic cycle.-Circulation of water from the oceans, through the atmosphere, to the land, and its eventual return to the atmosphere by way of evaporation from the ocean and land surfaces.

Hydrologic methods.-Refers to the computerized prediction of flood-flow volumes and maximum flood-stage height of rivers for either 100-year floods or the maximum flood of record.

Interbedded.-Beds between or alternating with others of different character.

Interfluve.-Area between rivers, especially the upland or ridge between two adjacent river valleys.

Isopach.-Line drawn on a map through points of equal thickness of a stratigraphic unit or group of stratigraphic units.

Large-scale map.-Map drawn at a scale that shows a small physical area in fine detail and accuracy (in the United States, larger in scale than $1: 62,500$, such as $1: 50,000$ )

Leached.-Having been subjected to leaching-the removal of soluble substances from rock or soil by the natural action of percolating water.

Lee Formation.-A sequence of thick pebbly quartz sandstone beds, interbedded with siltstone, shale, and coal. Bottommost sandstone bed usually marks the base of Pennsylvanian-age rocks in area. Named from Lee County, Va., where it was first described.

Limestone.-A sedimentary rock consisting of more than 50 percent by weight of calcium carbonate.

Lithology.-Physical character of a rock, or the description of rocks on the basis of such characteristics as color, structures, mineral composition, and grain size.

Low base flow.-Sustained or "fair-weather" flow of a stream at a relatively low level.

Mantle.-General term for a cover or blanket of surficial materials overlying bedrock. 
Mass movement.-Downslope movement of material under the influence of gravity and outside of stream channels.

Meander-belt lowland.-Zone along a valley floor across which a meandering stream shifts its course. This zone is defined as the area of the flood plain included between two lines drawn tangentially to the outside curves of all fully developed meanders.

Meander bend.-One of a series of somewhat regular curves, bends, loops, or windings in the course of a stream.

Microclimate.-Essentially uniform local climate of a small site.

Mineral fuels.-Coal, oil, gas. Fuels of organic origin that have undergone geologic processes or alteration.

Multiple-purpose land use.-(1) Static-several coexisting land uses; (2) sequential-a sequence of land uses planned so that one use prepares the way for the next use.

Natural systems.-Systems and relationships found in nature, including the relationships between geology, hydrology, and biology.

Outcrop.-.Surface exposure of a geologic bed or formation.

Overthrust fault.-Low-angle large-scale thrust fault. Thrust faulting is the overriding movement of one crustal unit over another as a result of horizontal compression.

Pennsylvanian age.-The period of geologic time during which the greatest accumulation of coal occurred. Named for Pennsylvania where rocks of this age were first described.

Permeability.-Ability of a material to allow the entrance, passage, or withdrawal of water.

Physiography.-Description of the physical features of the earth's surface.

Quartzose.-Composed predominantly of the mineral quartz.

Reconnaissance.-General exploratory examination or survey of the main or specific features of a region conducted as a preliminary to a more detailed survey.

Relict deposit.-Surviving vestige of a preexisting deposit that has been almost completely removed by erosion.

Remnant (erosional remnant).-_A feature such as a hill composed of resistant material that remains after the surrounding less resistant material has been eroded away.

Residuum.-Residue produced by weathering processes.

Resistant ledge.-Outcrop of sandstone beds that has withstood destructive weathering processes.

Ridge and ravine.-Topography characterized by a succession of parallel or nearly parallel ridges and ravines (or valleys) resulting from differential erosion of bedrock of varying resistance.

Rill.-Very small brook or stream of water; or small eroded channel, especially in soil.

Rim rock.-Horizontal layer of resistant rock exposed on the edge of an overlying plateau that forms a cliff or ledge overlooking lower ground.

Sandstone.-A sedimentary rock composed of sand-sized fragments in a silt or clay matrix and united by a cementing material such as silica, iron oxide, or calcium carbonate; (1) pebbly-contains abundant pebbles; (2) quartzose-contains mostly quartz sand grains. 
Sediment.-Organic or inorganic material originating from the weathering of rocks, chemical precipitation, or secretion from organisms. Sediments form in layers in a loose unconsolidated form and include sand, gravel, silt and mud.

Shale.-Fine-grained sedimentary rock formed by the compression of clay, silt, or mud.

Slope stability.-Ability of a slope to resist failure by landsliding.

Slump.-Landslide characterized by rotation movement around a horizontal axis of earth materials along a curved, concave-upward shear surface.

Small-scale map.-Map drawn at a scale (less than 1:62,500, such as $1: 100,000)$ that covers large areas but shows only generalized detail.

Spur.-A small ridge that projects sharply (at right angles to or in a lateral direction) from the crest or side of a hill, mountain, or other highland surface.

Strata.-Sedimentary bed of any thickness.

Stratigraphic.--Pertaining to stratigraphy.

Stratigraphy.-The definition and study of natural divisions of rocks by means of form, origin, environment, lithology, age, history, and other characteristic features.

Sulfate ion $\left(\mathrm{SO}_{t}^{-2}\right)$.- The anion of sulfuric acid.

Surficial geology.-Geology of surficial or surface materials and deposits, including soils and bedrock at or near the Earth's surface.

Sustained yield.-Yield from a forest or mine that is steady and continuous over a given period of time.

Toe.-Lower part of a slope or cliff. In mass movement, the toe is the lowermost extent of disturbed material on an undisturbed slope.

Topography.-Surface expression or configuration of the Earth's surface, including relief and position of natural and manmade features.

Topographic relief.-Vertical difference in altitude between hilltops and lowlands of a given region. An area showing a great variation in altitude has "high" relief, whereas one showing little variation has "low" relief.

Tributary.-Stream joining or flowing into a larger stream or lake.

Unconsolidated materials.-Surficial materials, such as alluvium or colluvium that have not been cemented together by calcium carbonate, iron oxide, or silica. Unconsolidated materials can be dug with a shovel.

Waste back.-To cut back, or retreat as the result of erosion. Slopes subject to landsliding gradually waste back as material is shifted downslope and removed, so that the crest of the slope retreats relative to its original position.

Watershed.-Drainage basin. The region drained by or contributing water to a stream, lake, or other body of water.

\section{REFERENCES CITED}

Briggs, R. P., 1957, Coal resources of the Campton quadrangle, Wolfe, Lee, and Breathitt Counties, Kentucky: U.S. Geol. Survey Coal Inv. Map $\mathrm{C}-42$.

Davis, R. W., 1977a, Map showing availability of ground water in Kentucky River Area Development District, Kentucky: U.S. Geol. Survey, Misc. Field Studies Map MF-865-D (in press). 
$1977 \mathrm{~b}$, Map showing data on flow of streams, drainage areas, and flood-prone areas in Kentucky River Area Development District, Kentucky: U.S. Geol. Survey Misc Field Studies Map MF-865-H (in press). -1977c, Map showing dissolved solids content and $\mathrm{pH}$ of water in selected streams in Kentucky River Area Development District, Kentucky: U.S. Geol. Survey Misc. Field Studies Map MF-865-G (in press). -1977d, Map showing quality of ground water in Kentucky River Area Development District, Kentucky: U.S. Geol. Survey Misc. Field Studies Map MF-865-E (in press).

1977e, Map showing sulfate in selected streams in Kentucky River Area Development District, Kentucky: U.S. Geol. Survey Misc. Field Studies Map MF-865-F (in press).

Newell, W. L., 1977a, Surficial geologic map of Kentucky River Area Development District and vicinity, eastern Kentucky: U.S. Geol. Survey, Misc. Field Studies Map MF-865-B.

—1977b, Surficial geologic maps of the Beattyville, Campton, and Hazard North quadrangles, Kentucky River Area Development District, eastern Kentucky: U.S. Geol. Survey Misc. Field Studies Map MF-843.

$-1977 \mathrm{c}$, Map showing slope stability in the Beattyville quadrangle, Kentucky River Area Development District, eastern Kentucky: U.S. Geol. Survey Misc. Field Studies Map MF-844.

Newell, W. L., and Rice, C. L., 1977a, Bedrock geologic map of Kentucky River Area Development District and vicinity, eastern Kentucky: U.S. Geol. Survey Misc. Field Studies Map MF-865-A.

1977b, Map showing original (premining) distribution of coal in Kentucky River Area Development District and vicinity, eastern Kentucky: U.S. Geol. Survey Misc. Field Studies Map MF-865-C.

Seiders, V. M., 1964, Geology of the Hazard North quadrangle, Kentucky: U.S. Geol. Survey Geol. Quad. Map GQ-344.

U.S. Geological Survey, 1974a, Beattyville, Ky. [slope map]: Reston, Va., scale $1: 24,000$.

1974b, Campton, Ky. [slope map]: Reston, Va., scale 1:24,000.

$-1974 \mathrm{c}$, Hazard North, Ky. [slope map] : Reston, Va., scale 1:24,000.

-1975, Land use and land cover, 1972, Kentucky River Area Development District (KRADD) : U.S. Geol. Survey Misc. Field Studies Map MF-683.

U.S. Soil Conservation Service, 1974, Soil survey of Estill and Lee Counties, Kentucky, by J. H. Newton [and others]: Washington, D.C., U.S. Govt. Print. Off., 87 p., 65 folded maps.

Verhoef, Mary, 1917, Kentucky River navigation: Louisville, Ky., J. P. Morton \& Co., $257 \mathrm{p}$.

Wilson, E. N. and Sutten, D., 1976, Oil and gas map of Kentucky, sheet 4, eastern part: Kentucky Geol. Survey, ser. 10. 



$$
\text { - }
$$

